$10-1-2010$

\title{
Brave New Eugenics: Regulating Assisted Reproductive Technologies in the Name of Better Babies
}

Kerry L. Macintosh

Santa Clara University School of Law, kmacintosh@scu.edu

Follow this and additional works at: http://digitalcommons.law.scu.edu/facpubs

Part of the Bioethics and Medical Ethics Commons, $\underline{\text { Health Law Commons, and the Legislation }}$ Commons

\section{Automated Citation}

Kerry L. Macintosh, Brave New Eugenics: Regulating Assisted Reproductive Technologies in the Name of Better Babies, 2010 U. ILL. J. L. Тесн. \& Pol'y 257 (2010),

Available at: http://digitalcommons.law.scu.edu/facpubs/42 


\section{BRAVE NEW EUGENICS: REGULATING ASSISTED REPRODUCTIVE TECHNOLOGIES IN THE NAME OF BETTER BABIES}

Kerry Lynn Macintosh $\dagger$

\section{TABLE OF CONTENTS}

I. Introduction 258

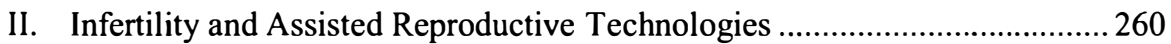

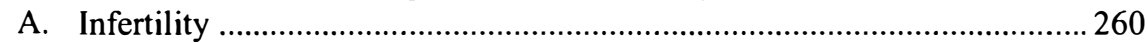

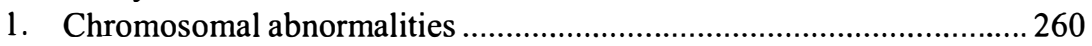

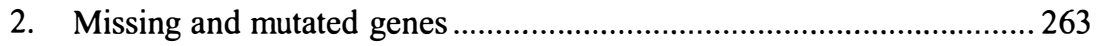

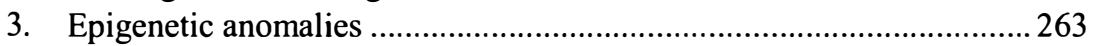

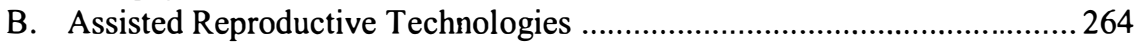

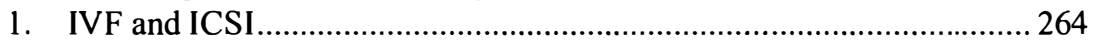

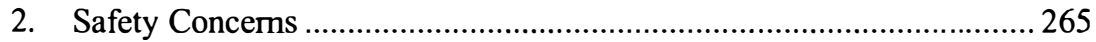

III. The Trend Towards Increased Regulation ................................................. 268

A. The Food and Drug Administration .......................................................... 269

1. Reproductive Cloning and Nuclear Transfer: Public Hysteria and

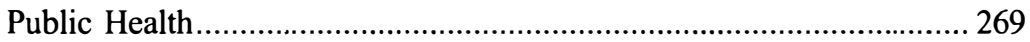

2. Ooplasm Transfer: Dangerous Technology or Treatment for Middle-Aged Women?....................................................................... 271

3. The FDA Asserts Questionable Authority to Regulate the Procreation of Infertile Men and Women ........................................... 272

B. The President's Council on Bioethics ...................................................... 275

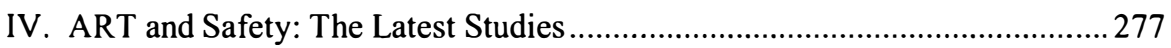

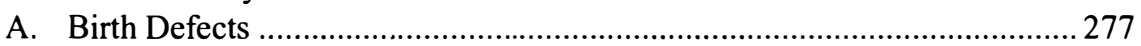

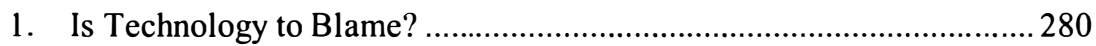

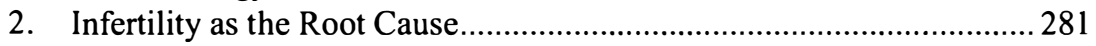

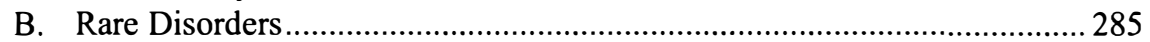

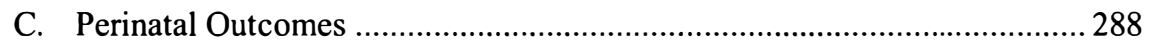

V. Eugenics in the Twenty-First Century ...................................................... 291

A. Legislative Bans and Regulatory Impediments ..................................... 292

B. Brave New Eugenics ...................................................................... 293

$\dagger$ Professor of Law, Santa Clara University School of Law. I thank Professor Paul A. Lombardo for graciously dirceting me to resources that enriched my work. I am also decply grateful to Professors Carol Sanger, Gary Spitko and Michelle Obcrman for their helpful advice and encouragement. Finally, I thank Michelle Woodhouse, Jason Mendelson, Shannon Pedersen, Kcvin Isaacson, and Ashlcy Richardson for their outstanding rescarch assistance. 
1. Eugenic Sterilization in the Twentieth Century ...................................293

2. Infertile Men and Women Are Disabled............................................... 296

3. Transmission of Health Problems ........................................................ 298

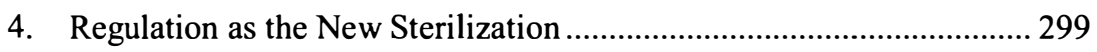

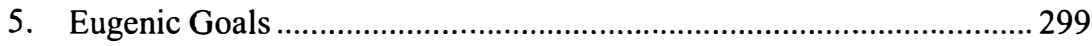

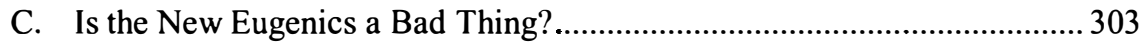

1. Coercive Reproductive Policies …...................................................... 304

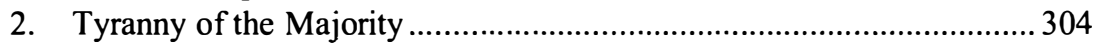

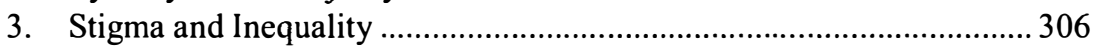

4. Science and Politics ............................................................................. 307

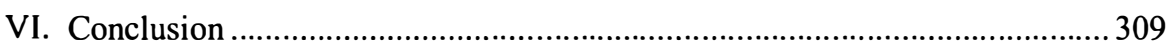

\section{Abstract}

Infertile men and women have been using assisted reproductive technologies (ART) to conceive children since the first "test-tube baby" was born in 1978. During the past decade, however, the federal government has begun to clamp down on ART, asserting safety concerns as grounds for banning novel technologies such as cloning, nuclear transfer, and ooplasm transfer.

Some scholars and policymakers now want to extend governmental regulation to include conventional ART such as in vitro fertilization (IVF) and intracytoplasmic sperm injection (ICSI). They claim children conceived through ART face an increased risk of birth defects and other health problems.

This Article examines the medical literature and exposes a key fact: the health problems observed in such children may be linked to the underlying characteristics of their infertile parents, rather than ART as such. Viewed in light of this literature, the demand for increased regulation amounts to an attempt to restrict the reproduction of disabled persons (the infertile) on the ground that their unhealthy offspring should never be born. But, this is the same rationale eugenicists once used to justify enacting the sterilization laws of the twentieth century.

This Article concludes society should reject this new form of eugenics. The fertile majority should not enact coercive laws and regulations that undermine reproductive autonomy, oppress the infertile minority, stigmatize children, and weaken our commitment to egalitarianism.

\section{INTRODUCTION}

Assisted reproductive technologies $(A R T)^{1}$ have a compassionate purpose: to allow infertile men and women to bypass their physical disabilities

1. Like federal law, this Article defines assisted reproductive technologies as treatments or procedures that involve handling cggs or cmbryos outside the body, including in vitro fertilization (IVF), gametc intrafallopian transfer (GIFT), zygote intrafallopian transfer (ZIFT), and intracytoplasmic spern injection (ICSI). See Fertility Clinic Success Rate and Certification Act of 1992, 42 U.S.C. § 263a-1, 263a-7 (2006) ("The tern 'assisted reproductive technology' means all treatments or procedures which include the handling of human oocytes or cmbryos, including in vitro fertilization, gametc intrafallopian transfer, zygote intrafallopian transfer, and such other specific technologies as the Secretary may include in this definition...."). 
and conceive genetic offspring. ${ }^{2}$ Since in vitro fertilization (IVF) was first introduced in 1978, more than three million children have been born worldwide through ART. ${ }^{3}$

There are storm clouds on the horizon, however. During the past twelve years or so, the federal government has begun to take a strong interest in ART. Asserting concerns for the safety of children, the Food and Drug Administration has reached beyond its statutory authority to stop novel technologies such as human reproductive cloning, nuclear transfer, and ooplasm transfer. ${ }^{4}$

This regulatory tempest now threatens to engulf standard technologies such as IVF. Legal academics and federal policymakers argue that children conceived with the aid of ART face higher rates of birth defects, low birth weight, and other health problems. Their recommendations include undertaking massive new studies of child health, creating new regulatory agencies, and limiting access to problematic technologies, all in the name of public health. $^{5}$

However, the debate over the regulation of ART is incomplete in two significant ways. First, regulators and academics have only skimmed the surface of a complex body of medical literature. ART may not be to blame for health problems observed in children. In fact, there are good reasons to believe these problems stem from underlying characteristics of infertility patients. ${ }^{6}$

Second, the debate has ignored the eugenic implications of governmental control over ART. When access to reproductive technologies is restricted, the consequences are dramatic: infertile men and women are rendered unable to procreate, and children who might otherwise have been born with health problems are never born at all. They are eliminated, along with their disabilities, ostensibly for their own good.

These twin deficiencies have skewed the debate. This Article seeks to correct them before regulators and legislators do anything more to restrict access to ART.

Part I describes infertility, ART, and concerns about the safety of children. Part II recounts the story of how the federal government has begun to seize control over the reproductive choices of infertile men and women from blocking access to specific technologies to demanding studies as a platform for further regulation.

This Article then shifts the paradigm in two ways. First, Part III evaluates the medical literature on the health of children conceived through ART. Reaching beyond the simple conclusion that the technologies themselves are to blame, it explains that infertile men and women have certain characteristics that could provide an alternative account for the health problems observed in offspring.

2. See discussion infra Part I.

3. Carolinc Ryan, More Than 3m Babies Born from IVF, BBC NEws, Junc 21, 2006, http://news.bbc.co.uk/2/hi/health/5101684.stm.

4. See infra Part II.A.

5. See infra text accompanying notes $78-91$ and $153-68$.

6. See infra Part III. 
Second, Part IV uses this medical data to reevaluate demands for increased regulation of ART. If lawmakers and regulators accede to these demands, they will be restricting the reproduction of infertile men and women because they are prone to conceiving children with health problems. Drawing a historical analogy, Part IV explains how such action would be comparable in effect and purpose to the sterilization laws of the twentieth century. It argues against this new form of eugenics, reasoning that the fertile majority should not use democratic institutions to oppress the infertile minority and stigmatize them and their children. Nor should the state arrogate to itself the power to decide who is perfect enough to be born.

\section{INFERTILITY AND ASSISTED REPRODUCTIVE TECHNOLOGIES}

This Part begins with a discussion of infertility and some of its causes. Next, it explains technologies used to treat infertility. It concludes by describing the existing regulatory regime and proposals for reform.

\section{A. Infertility}

Infertility is a common affliction in the United States. It affects about 7.3 million women and their partners, or around $12 \%$ of the reproductive population. $^{7}$

Infertility has many causes, including obesity and venereal diseases that scar reproductive organs and pathways. ${ }^{8}$ This article will focus on biological factors that not only make it hard for men and women to conceive, but also pose risks to the health of their children.

\section{Chromosomal abnormalities}

Human reproduction is inefficient. Up to $75 \%$ of all human embryos are lost. ${ }^{9}$ Most fail to implant or miscarry before the prospective mother even realizes conception has occurred. ${ }^{10}$ From $30-60 \%$ of these embryonic losses are due to chromosomal abnormalities. ${ }^{11}$

\section{a. Aneuploidy}

A human embryo is supposed to have two copies of each of the twentytwo autosomal chromosomes, plus two sex chromosomes (one $\mathrm{X}$ coupled with either one $\mathrm{Y}$ or another $\mathrm{X}$ ). Through sperm and egg, father and mother each

7. U.S. Dep't of Health \& Human Servy., Ctrs. for Disease Control \& Prevention, Fertility, Family Planning, and Reproductive Health of U.S. Women: Data from the 2002 National Survey OF FAMILY GROWTH 29 (2005), available at http://www.cdc.gov/nchs/data/scrics/sr_23/sr23_025.pdf ("Of the 61.6 million women of reproductive age in $2002,12 \%$ ( 7.3 million women) had ever used some kind of medical help, either to become pregnant or to prevent miscarriage.").

8. Rebecca Smith, IVF 'Creating an Infertility Timebomb, 'DAILY TELEGRAPH, Fcb. 15, 2008, http://www.telegraph.co.uk/ncws/uknews/1578752/IVF-\%27creating-an-infertility-timcbomb\%27.html.

9. Toby Ord, The Scourge: Moral Implications of Natural Embryo Loss, 8 AM. J. BIOETHICS 12, 16 (2008) ("The figures for carly spontancous abortion (within the first 6 wecks) range from $45 \%$ t o $75 \%$....").

10. Id.

1I. Id. at 17 
contribute one chromosome to each of the twenty-three pairs. ${ }^{12}$

However, sometimes a sperm or egg carries more (or less) than the standard single copy of a particular chromosome. An embryo made from that defective sperm or egg will be aneuploid - that is, have more (or less) than the standard two copies of that chromosome. ${ }^{13}$ Such embryos either miscarry or produce abnormal offspring. For example, trisomy 21 (three copies of chromosome 21 ) ordinarily causes miscarriage but occasionally produces a child with Down syndrome. ${ }^{14}$

What causes these numerical errors? Age is one factor. ${ }^{15}$ A woman is borm with her eggs. As she ages, her eggs get older too. Older eggs are not as efficient at preparing for fertilization through meiosis (a process that involves recombination of genes). ${ }^{16}$ The increase in aneuploid conceptions helps explain why pregnancy rates decline at age thirty-two and drop sharply at age thirty-seven. ${ }^{17}$ Moreover, if an older woman does get pregnant, her child may be abnormal. Only $2 \%$ of clinically recognized pregnancies are trisomic in women under the age of twenty-five, but $35 \%$ of such pregnancies are trisomic in women over forty. ${ }^{18}$

However, not all women are created equal in this regard. Some start out with fewer eggs, and thus have fewer eggs in reserve (ovarian reserve). ${ }^{19}$ Studies have found that women who produce trisomic fetuses have reduced ovarian reserve and reach menopause one year earlier on average than other women. $^{20}$ Thus, biological age may be more important than chronological age.

In addition, studies have shown that, regardless of age, infertile women are more likely to produce aneuploid eggs and embryos. ${ }^{2 P}$ Some underlying characteristic of infertile women causes their eggs and embryos to be more prone to numerical errors than the eggs and embryos of fertile women. ${ }^{22}$

Men produce fresh sperm daily and the risk of chromosomal abnormalities does not rise as sharply with advancing age. ${ }^{23}$ Studies have found only $1-2 \%$ aneuploid sperm in normal men. ${ }^{24}$

12. See James Evans ct al., Genetics, in SCIENCE FOR LAwYERS 175, 186 (ERIC York Drogin ED. 2008).

13. Sherman J. Silber, how to Get Pregnant 300 (Little, Brown \& Co. rev. cd. Sept. 2005, paperback cd. Aug. 2007).

14. $80 \%$ of trisomy 21 cmbryos miscarry. Id. at 293 .

15. Id. at 299 .

16. Id. at 298. See also id, at 294-97 (explaining meiosis)

17. Id. at 275 .

18. Renec H. Martin, Meiotic Errors in Human Oogenesis and Spermatogenesis, 16 REPROD. BIOMEDICINE ONLINE 523, 524 (2007).

19. SILBER, supra notc 13 , at 49.

20. See Martin, supra note 18, at 524 (discussing possible risk factors leading to ancuploid concepti).

21. See id. at 525 (comparing "ancuploidy frequencies" of embryos among fertile and infertile donors).

22. Id.

23. SILBER, supra note 13 , at 336 . One recent study examined more than five million births in the United States and concluded paternal age had relatively little impact on the rate of birth defects. Q. Yang et al., Paternal Age and Birth Defects: How Strong Is the Association?, 22 HUM. REPROD. 696 (2007). Compared with fathers age twenty-five to twenty-nine, fathers in their forties faced an $8 \%$ increase in the risk of producing offspring with birth defects, while those fifty and older had an increased risk of $15 \%$. See id. at 697 tbl. 1 (displaying data for prevalence of, and relative risks for, birth defects by patemal age group).

24. See Martin, supra note 18, at 525 (discussing incidence of chromosome abnormalitics in human sperm). 
However, infertile men with any type of sperm problem (e.g., little or no sperm in the ejaculate, motility defects, or abnormal shape) are two to ten times more likely than normal men to generate aneuploid sperm. ${ }^{25}$ Whatever genetic weakness causes a problem in creating normal sperm can also lead to aneuploidies. $^{26}$

\section{b. Translocations}

Aneuploidies are not the only kind of chromosomal problem. Some men and women are carriers of structural chromosomal abnormalities. ${ }^{27}$ The most common are translocations in which pieces of one chromosome are swapped with or stuck onto a chromosome of a different number. ${ }^{28}$

A carrier of a "balanced" translocation is healthy because he or she has the right number of genes even though pieces of his or her chromosomes are misplaced. ${ }^{29}$ Balanced translocations include Robertsonian (e.g., chromosome 13 fuses to chromosome 14) and reciprocal (e.g., chromosome 14 exchanges parts with chromosome 15). ${ }^{30}$

Robertsonian translocations are rare, occurring in one out of 1000 newborns. ${ }^{31}$ However, in men with low sperm count, the rate can rise to one or two out of $100 .^{32}$

Reciprocal translocations occur in one out of 1000 newborms, but the average rate in infertile men runs higher, around seven in $1000 .^{33}$ Wives of men seeking fertility treatment have been found to harbor a similar seven in 1000 rate of reciprocal translocations. ${ }^{34}$

When these infertile carriers of balanced translocations reproduce, their sperm and eggs must undergo genetic recombination in preparation for fertilization. Some will receive the correct number of genes, while others will carry duplicated or deleted chunks of chromosome. Such defective sperm and eggs lead to abnormal embryos and miscarriages. On rare occasions, a fetus that carries surplus or missing genes survives and a child is born with serious birth defects. ${ }^{35}$

25. See id. at 526 (indicating that ancuploidies occur both in the autosomal chromosomes I through 22 and in the sex chromosomes $\mathrm{X}$ and $\mathrm{Y}$ ).

26. See id. (indicating an "association of increased sperm ancuploidy frequencies in infertile men").

27. Genome Abnormality Fact Shcct, NATIONAL Human GeNOME RESEARCH INSTITUTE, http://www.genome.gov/11508982\#al-5 (last visited Scpt. 1 1, 2010).

28. Id.

29. SILBER, supra notc 13, at 303.

30. Id.

31. Jcan Picrrc Siffroi, Symposium: Genetic and Epigenetic Aspects of Assisted Reproduction, Underlying Karyotype Abnormalities in IVF/ICSI Patients, 16 REPROD. BIOMEDICINE ONLINE, 514, 517 (2008), www.rbmonlinc.com/Article/3221.

32. Id.

33. Id.

34. Id. at 519.

35. See SILBER, supra note 13, at 303-05 (describing translocations and their consequences in human reproduction). 


\section{Missing and mutated genes}

More subtle chromosomal and genetic defects can also lead to infertility and abnormal offspring. For example, the $\mathrm{Y}$ chromosome is believed to carry many of the genes necessary to the production of healthy sperm. ${ }^{36}$ Even in fertile men, the random process of genetic recombination always produces a few defective sperm that delete chunks of the $\mathrm{Y}$ chromosome. ${ }^{37}$ Sons conceived with this sperm are likely to have poor-quality sperm of their own. ${ }^{38}$ They, in turn, will transmit the $\mathrm{Y}$ chromosome deletion to their sons, and infertility along with it. ${ }^{39}$

The $\mathrm{X}$ chromosome may also carry genes related to sperm and egg production. ${ }^{40}$ Deletions or mutations of genes on the $\mathrm{X}$ chromosome can lead to infertility and birth defects in offspring.

And there is more to be learned. With the help of advanced technologies, scientists are working to identify other structural chromosomal defects and gene mutations that contribute to infertility. ${ }^{42}$

\section{Epigenetic anomalies}

DNA contains more than the genetic information in its nucleotide sequence. In its structure it holds epigenetic information that affects the expression of genes. ${ }^{43}$

Chemical markings known as "imprints" are particularly important. Recall that a mother (through her egg) and a father (through his sperm) each contribute one set of chromosomes to an embryo. ${ }^{44}$ Thus, most genes occur in two copies and both are expressed. ${ }^{45}$ However, imprints control expression of certain key developmental genes, so that only the maternal or paternal copy is active. $^{46}$ If anything is wrong with the imprints, gene expression will be

36. Id. at 317 .

37. Id. at 318-19.

38. Id. A normal man who produces 200 million sperm in his cjaculate will produce 100,000 sperm with a Y chromosome deletion per day (1\%). The odds are against the defective sperm, but if one fertilizes an egg, an infertilc baby boy may result. Id. at 322 .

39. See David C. Page ct al., Men with Infertility Caused by AZFc Deletion Can Produce Sons by Intracytoplasmic Sperm Injection, but Are Likely to Transmit the Deletion and Infertility, 14 HUM. REPROD. 1722,1722 (1999) (stating that sons inherit the Y chromosome delction which can causc infertility).

40. See SiLBER, supra note 13, at 320-24 (cvidencing the $X$ chromosome's rolc in cgg and sperm production through the examples of Kallman's syndrome, where a chromosomal abnormality causcs sterility in malc descendants, and Turner syndrome, where women have only onc X chromosome and produce no cggs).

41. See id. at 324 (stating that women who carry excessive repeats of a certain gene on the $X$ chromosome are at risk both for premature ovarian failure and concciving offspring with fragile $\mathrm{X}$ syndrome, a source of mental retardation).

42. See Martin M. Matzuk \& Dolores J. Lamb, The Biology of Infertility: Research Advances and Clinical Challenges, 14 NATURE MED. 1197, 1207, 1209 (2008) (stating that mice testing is providing ncw insights about fertility genes).

43. See Kerry Lynn macintosh, Illegal Beings: Human Clones and the Law, 52 (Cambridge Univ. Press 2005) ("Epigenetic information influences how genes are expressed....") (citing Richard M. Twyman, AdvanCED MOLECUlar BIOLOGY: A CONCISE REFERENCE, at 93 (reprinted cd. 1999).

44. See Evans ct al., supra note 12, at 186 (discussing the inheritance of human chromosomes).

45. MACINTOSH, supra notc 43, at 52 ("Most genes are expressed on both maternal and paternal chromosomes; however, genes subject to parental imprinting are expressed only on either the matemal or patcrnal chromosomc.") (citing Twyman, supra notc 43, at 97).

46. Id. 
abnormal and the embryo may not develop properly. ${ }^{47}$

Thus, there are two ways that epigenetic errors can cause problems. First, such errors may cause or contribute to infertility. ${ }^{48}$ For example, imprinting errors have been found in the sperm of infertile men, especially those who suffer from low sperm count. ${ }^{49}$

Second, epigenetic errors in eggs and sperm may have health consequences for children. For example, Japanese researchers examined miscarried embryos conceived through ART. ${ }^{50}$ Seventeen out of seventy-eight samples $(21.8 \%)$ had imprinting errors affecting genes necessary for the proper development of the embryo. ${ }^{51}$ But, in seven of seventeen affected samples (41\%), the same imprinting error was present in the sperm of the father, indicating that the epigenetic flaw had been transmitted. ${ }^{52}$

Other researchers have suggested that infertile men and women might be genetically predisposed to produce gametes and embryos that are unstable at the epigenetic level. ${ }^{53}$ Environmental influences in the womb or elsewhere could lead to loss of epigenetic regulation and alteration of the developmental trajectory of the embryo. ${ }^{54}$ This would not only make it harder to conceive, but also increase the risk of health problems in offspring. ${ }^{55}$

\section{B. Assisted Reproductive Technologies}

\section{IVF and ICSI}

Some infertile men and women who suffer from chromosomal, genetic, and epigenetic problems will turn to in vitro fertilization (IVF). In the standard IVF protocol, the prospective mother takes one kind of drug (gonadotropin releasing hormone agonist) to suppress her natural cycle and another (gonadotropin) to stimulate the production of multiple eggs. ${ }^{56}$ Following administration of a third drug (human chorionic gonadotropin) to mature the eggs, a doctor aspirates the eggs using a needle inserted into the ovaries

47. See id. at 51-61 (discussing the observed and potential effects of abnormal genetic imprinting on gene expression in clones of animals and humans).

48. See Hisato Kobayashi ct al., DNA Methylation Errors at Imprinted Loci After Assisted Conception Originate in the Parental Sperm, 17 EURO. J. HuM. GENETICS 1582, 1589 (2009) (cxplaining that gene alterations arc linked to infertility).

49. See Douglas T. Carrell \& Sahcr Suc Hammoud, The Human Sperm Epigenome and Its Potential Role in Embryonic Development, 16 MOLECULAR HUM. REPROD. 37, 42 (2010) (stating that men with low sperm counts have altered DNA methylation); Kobayashi et al., supra note 47, at 1583 (stating that "methylation errors are present at imprinted loci in the sperm of infertile men, particularly those with oligospermia.").

50. See Kobayashi et al., supra note 46 , at 1585 (explaining study that looked at aberrant maternal methylation in ART samples).

51. Id. at 1589.

52. Id. (stating that in seven cases "the same imprinting errors were present in the parental sperm and the matched ART sample, suggesting that abnormal hypomethylation at H19 and GTL2 was transmitted directly from the father's sperm.").

53. See Bernhard Horsthemke \& Michacl Ludwig, Assisted Reproduction: The Epigenetic Perspective, II HUM. REPROD. UPDATE 473, 474 (2005) (discussing the possibility "that some subfertile couples have a genetic predisposition to epigenetic instability....").

54. See id. at 479-80 (discussing "the loss of epigenetic control").

55. See infra notes 205-09 and accompanying text.

56. See SILBER, supra note 13, at 174-76, 201-02 (describing the nature and use of these medications). 
through the vaginal wall. ${ }^{57}$ The eggs are taken to the lab and mixed with a sperm sample obtained from the intended father. ${ }^{58}$ After conception, embryos are cultured for three to five days and then transferred back into the uterus of the intended mother, who takes progesterone supplements to ensure that the uterine lining is receptive. ${ }^{59}$

Infertile men whose sperm are few in number, malformed, or incapable of penetrating an egg can still participate in IVF with the aid of intracytoplasmic sperm injection (ICSI). ${ }^{60}$ Lab technicians equipped with microscopes and tiny glass needles seize individual sperm and inject them directly into eggs to achieve fertilization. ${ }^{61}$ Pioneered in Belgium in 1991, ICSI has overcome most male-factor infertility. ${ }^{62}$ Even when men have no sperm in their ejaculate, a few sperm can often be recovered from the epididymis or the testes.

\section{Safety Concerns}

Since IVF and ICSI were invented, authorities have regulated with a light hand and primarily for the benefit of the men and women who use the technologies. Federal law is minimal. Congress has granted would-be parents access to fertility clinic success rates, ${ }^{64}$ and the Food and Drug Administration (FDA) approves drugs, devices, and biological products that are used in fertility treatments. ${ }^{65}$ FDA regulations also protect patients who undergo ART against transmission of communicable diseases. ${ }^{66}$

States impose somewhat more control. As part of their general oversight of medical practice, they license doctors, discipline them, and subject them to liability in tort if they fail to provide informed consent or exercise reasonable care. $^{67}$ Some states have laws that are specific to ART, but most of these

57. See id. at 177-78 (discussing administration of human chorionic gonadotropin) and 220-22 (dcscribing the procedure for cgg retricval).

58. See id. at 222-23, 233 (discussing sperm prcparation and culturc with cggs).

59. See id. at 179 (discussing use of progesterone to support pregnancy), 233-35, 243 (describing culture of cmbryos and transfer to uterus).

60. MACINTOSH, supra note 43, at 13.

61. See SILBER, supra note 13, at 260-65 (describing the "Step-by-Step Details of the ICSI Procedure"). ICSI was used in nearly half of all ART cycles in 2001. PRESIDENT'S COUNCIL ON BIOETHICS, REPRODUCTION AND RESPONSIBILITY: THE REgUlation OF NEW BIOTECHNOLOGIES 27 (2004) [hereinafter REPRODUCTION AND RESPONSIBILITY] (suggesting that some doctors and patients are turning to ICSI as "insurance" that fcrtilization will occur); see also SILBER, supra note 13, at 270 (suggesting that there are no significant differences in overall ART results when undergoing conventional IVF versus ICSI).

62. SILBER, supra note 13 , at 250-52, 265-67.

63. See id. at 267-69 (describing how doctors are able to retrieve sperm from the testicles or the epididymis).

64. See Fertility Clinic Success Rate and Certification Act of 1992, 42 U.S.C. § 263a-1-a-7 (2006) (stating clinics must report success rates and other data to the Centers for Disease Control and Prevention, which publishes most of that information in annual reports for consumers); see also REPRODUCTION AND RESPONSIBILITY, supra note 61, at 47-51 (describing the Act and its implementation).

65. See REPRODUCTION AND RESPONSIBILITY, supra note 61, at 54-62, (providing a thorough discussion of how the FDA exercises its authority).

66. The FDA has assumed limited control over sperm banks and ART clinics and labs. See generally 21 C.F.R. $§ 1271$ (2008) (stating sperm banks and ART clinics and labs must register with the FDA, screen thirdparty donors for communicable diseases, and maintain records).

67. See REPRODUCTION AND RESPONSIBILITY, supra note 61, at 64-71 (describing state oversight and regulation for assisted reproduction). 
simply address whether insurers must cover infertility treatment. ${ }^{68}$

Private voluntary associations also play a role in regulating ART. The American Society for Reproductive Medicine (ASRM) ${ }^{69}$ publishes guidelines and statements on the medical practice and ethics of ART. It can expel members for noncompliance, but does not have the power to impose other penalties. $^{70}$ ASRM has a sister organization, the Society for Assisted Reproductive Technology (SART). SART member clinics must comply with ASRM guidelines and have their embryo labs inspected and certified. ${ }^{71}$

Some lawyers and legal academics disdain this minimalist regime and view the field of assisted reproduction as a dangerously unregulated "Wild West." A2 As Professor John Robertson notes, "[i]t has been a standard refrain in discussions of ART to bemoan the lack of regulation, and even call for a centralized system of regulatory control., 73

Critics have concerns about the welfare of children conceived through ART. Sometimes they focus on the manner in which assisted reproduction is practiced. For example, when a doctor transfers multiple embryos in a single IVF cycle, ${ }^{74}$ the patient may end up carrying twins or higher-order multiples. ${ }^{75}$ The babies may be born prematurely, at low birth weight, or with disabilities. ${ }^{76}$ The recent birth of octuplets spurred calls for legislation to limit the number of

68. Id. at 51. A few states, such as New Hampshire and Pennsylvania, comprehensively regulate ART. Other states have laws that regulate egg and sperm donation, outline parental rights and obligations, and limit research on embryos. Id. at 51-54.

69. According to its website, ASRM is a multidisciplinary organization dedicated to the advancement of reproductive medicinc. Its basic functions include education, rescarch, and advocacy on behalf of patients, doctors, and health care providers. ASRM: MISSION STATEMENT, http://asrm.org/detail.aspx?id=60 (last visited Sept. 14, 2010). Its membership includes doctors, nurses, biologists, laboratory technicians, and mental health professionals. Id.

70. See REPRODUCTION AND RESPONSIBILITY, supra note 61, at 72-73 (stating that "ASRM's system of professional sclf-regulation is voluntary and there appear to be no penaltics for or consequences of noncompliance.").

71. See id. at 71 (explaining that the organizations qualified to certify labs of SART members are the College of Amcrican Pathologists, the Joint Commission for Accreditation of Healthcare Organizations, and the New York State Tissue Bank program).

72. See Lori Andrcws, Genetics, Reproduction, and the Law, TRIAL, July I, 1999, at 20, 29 (discussing the reasons why ART is virtually unregulated by the government); Alexander N. Hecht, The Wild, Wild West: Inadequate Regulation of Assisted Reproductive Technology, 1 HOUS. J. HEALTH L. \& POL'Y 227, 237-24I (2001) (discussing the inadequacy of ART regulation).

73. John A. Robcrtson, Commerce and Regulation in the Assisted Reproduction Industry, 85 TEX. L. REV. 665, 699 (2007).

74. Data from 2007 show avcrage transfers of two to threc embryos during a single IVF cycle. See Ctrs. for Disease Control and Prevention, 2007 Assisted Reproductive TeChnology Success RATES: NATIONAL SUMMARY AND FERTILITY CLINIC REPORTS (2007), available at http://www.cde.gov/art/ART2007/PDF/COMPLETE_2007_ART.pdf [hereinafter 2007 ART REPORT] (discussing transfer statistics).

75. See Laura A. Schicve ct al., Are Children Born After Assisted Reproductive Technology at Increased Risk for Adverse Health Outcomes? 103 OBSTETRICS \& GYNECOLOGY 1154, 1155 (2004) [hereinafter Schieve I] (noting that $36 \%$ of ART pregnancies conceived in 2001 resulted in deliveries of multiples); 2007 ART REPORT (stating that $54 \%$ of ART infants born in 2000 werc part of a multiple birth compared with $3 \%$ of infants in the general population).

76. See REPRODUCTION AND RESPONSIBILITY, supra note 61, at 41 (stating that one in ten children born following a high-order pregnancy will die before their first birthday; the disabilities that multiples suffer include blindness, respiratory dysfunction, and brain damage; premature birth can lead to infection, respiratory distress, and heart defects; and that low birth weight may affect health throughout life, leading to hypertension, cardiac disease, stroke, and ostcoporosis.). 
embryos transferred in a single IVF cycle. ${ }^{77}$

More relevant here, however, are claims that IVF and ICSI are inherently unsafe for children. To establish this point, critics of ten cite two scientific studies published together in the New England Journal of Medicine in 2002.

In the first, Michele Hansen and her research team reviewed data from fertility clinics in Westem Australia and found a $9 \%$ rate of major birth defects in infants bom after IVF and an $8.6 \%$ rate of major birth defects in infants bom after ICSI. $^{78}$ This compared unfavorably with a control group of spontaneously conceived infants, who had a $4.2 \%$ rate of major birth defects. ${ }^{79}$

The second study came from the Centers for Disease Control and Prevention (CDC). Laura Schieve and her research team found that singletons conceived through ART were 2.6 times more likely than spontaneously conceived infants to have a low birth weight (2500 grams or less) even when borm at term (thirty-seven weeks gestation), and 1.4 times more likely to have a low birth weight when bom preterm. ${ }^{80}$ Curious about the cause, the team conducted analyses in which the sample was limited to singletons conceived with donor gametes, carried by surrogates, or bom from pregnancies that did not begin as multiple gestations. ${ }^{81}$ The risk of low birth weight remained elevated, at least for infants bom at term. ${ }^{82}$ The researchers inferred ART might cause low birth weight. ${ }^{83}$

Fertility doctors promptly criticized the Hansen and Schieve studies, suggesting that the poor outcomes observed could be due to infertility-related

77. Kimi Yoshino \& Jessica Garrison, Stricter Rules on Fertility Industry Debated, L.A. TIMEs Mar. 6, 2009 at I, http://articles.latimes.com/2009/mar/06/nation/na-octuplets-laws6. The fertility industry is already working to reduce embryos transferred in a single cycle. ASRM and SART guidelines recommend single embryo transfer for women under thirty-five with a more favorable prognosis, judged by criteria such as first IVF cycle, good quality embryos, and excess embryos that can be frozen and saved for later transfers. The Practice Comm. of the Soc'y for Assisted Reprod. Tech. and the Practice Comm. of the American Soc'y for Reprod. Med., Guidelines on the Number of Embryos Transferred, 90 FERTILITY \& STERILITY S163, SI63 (2008).

78. Michele Hansen et al., The Risk of Major Birth Defects After Intracytoplasmic Sperm Injection and In Vitro Fertilization, 346 NEw ENG. J. MED. 725, 728 tbl. 3 (2002) [hereinafter Hansen].

79. See id. at 725 (stating that $4.2 \%$ of the 4000 naturally conceived infants studied had a major birth defect). Major defects included cardiovascular, musculoskeletal, chromosomal, and urogenital. Id. at 730 . Interestingly, many contemporaneous studies reached the opposite conclusion, namely, that IVF and ICSI did not increase the rate of birth defects. See, e.g., Jamic Grifo \& Michacl Steinkampf, Major Birth Defects After Assisted Reproduction, 347 NEw. ENG. J. MED. 1449, 1449 (2002) ("Among 134,985 children conceived as a result of assisted reproductive technology between 1996 and 2000, 2597 infants (1.9\%) were reported to have a major birth defect. This rate is similar to the incidence of major abnormalities reported in general populations in both Europe and North America."); Matthew Retzloff \& Mark Hornstein, Is Intracytoplasmic Sperm Injection Safe? 80 FERTILITY \& STERILITY 851, 857 (2003) (stating that the slight increased risk of malformation for IVF offspring compared with the natural conception groups was "no longer statistically significant when confounding variables such as maternal age, parity, and cthnicity were controlled"). However, it was the Hansen study that captured media and academic attention.

80. Laura A. Schieve et al., Low and Very Low Birth Weight in Infants Conceived with Use of Assisted Reproductive Technology, 346 NEw ENG. J. MED. 731, 736 tbl. 4 (2002) [hereinafter Schieve II]. The children studied were borm in 1996 and 1997. The results did not change materially when researchers adjusted the data for matemal characteristics such as age and parity, or treatment factors such as use of ICSI. Id. at 733, 734 tbl. 2 .

81. Id. at 732 .

82. Id. at 733 .

83. See id. at 735 (suggesting that "the increased risk of low birth weight in singleton infants born at term who were conceived with assisted reproductive technology may be directly related to such treatments for infertility"). 
conditions rather than ART as such. ${ }^{84}$ In support, they noted that preterm singletons born to surrogates did not have an increased risk of low birth weight in the Schieve study. ${ }^{85}$ If the goal was to see if IVF and ICSI led to bad outcomes, the appropriate control population was not babies in general (most of whom are born to healthy, fertile men and women), but rather babies born to infertile men and women who conceived through methods other than IVF and ICSI. $^{86}$

Despite this key methodological weakness, the Hansen and Schieve studies grabbed attention. The media reported them as bad news on "test-tube babies" 87 and legal academics called for increased regulation.

For example, Professor Lars Noah argued in 2003 that the FDA should withdraw fertility drugs from the market (thus relegating patients to IVF performed with the single egg produced by a natural menstrual cycle). ${ }^{88}$ In 2004, Professor Jennifer Rosato cited the studies in support of her claim that IVF and ICSI place the safety of children at risk. ${ }^{89}$ In addition to increased state regulation, she recommended creation of a new federal agency that would consider safety and ethical concerns and ban or limit technologies considered harmful to children, such as ICSI. ${ }^{90}$ Similarly, in 2006, Professor Michael Malinowski urged that the United States adopt a comprehensive national licensing requirement for assisted reproduction services and create a new federal agency to oversee IVF and ICSI. ${ }^{91}$

\section{Ill. ThE TREND TOWARDS INCREASED REGULATION}

Academic calls for increased regulation coincide with an emerging federal trend. This Part documents how the FDA has used safety concerns to justify bans on reproductive cloning and cutting-edge ART such as nuclear transfer and ooplasm transfer. There are also signs that lawmakers and regulators may soon attempt to restrict access to conventional ART such as

84. See, e.g., George Kovalcvsky et al., Do Assisted Reproductive Technologies Cause Adverse Fetal Outcomes? 79 FERTILITY \& STERILITY 1270, 1270 (2003) (indicating that complications could be results of an infertility-related condition rather than the use of ART).

85. Id at 1271.

86. Id. at 1270 .

87. See, e.g., Test-tube Babies Have More Problems, S.F. CHRON., Mar. 7, 2002, at A-5

88. Lars Noah, Assisted Reproductive Technologies and the Pitfalls of Unregulated Bio-medical Innovation, 55 FLA. L. REV. 603, 603 (2003).

89. See generally, Jennifer Rosato, The Children of ART (Assisted Reproductive Technology): Should the Law Protect Them from Harm?, 2004 UTAH L. REV. 57, 84-94 (2004) (suggesting that artificially created children are generally at higher health risk).

90. Id Professor Marsha Garrison has suggested a quasi-public partnership between a private entity staffed by medical professionals and a federal agency such as the Department of Health and Human Services. The professionals would be responsible for drafting regulatory standards and updating them as necessary to accommodate new knowledge or practices. Following federal approval, the standards would become binding on fertility clinics. See also Marsha Garrison, Regulating Reproduction, 76 GEO. W ASH. L. REV. 1623, $1648-$ 49 (2008) (discussing the quasi-regulatory system in organ donation and implantation).

91. Michacl Malinowski, A Law-Policy Proposal to Know Where Babies Come from during the Reproduction Revolution, 9 J. GENDER RACE \& JUST. 549, 551 (2006). In a previous article Professor Malinowski had argued that the Centers for Discase Control or FDA should regulate ART, both to ensure safety and to control emerging practices that could give parents the power to screen embryos and select the genetic characteristics of their children. Michael Malinowski, Choosing the Genetic Makeup of Children: Our Eugenics Past-Present, and Future? 36 CONN. L. REV. 125, 218 (2003). 
IVF and ICSI.

\section{A. The Food and Drug Administration}

\section{Reproductive Cloning and Nuclear Transfer: Public Hysteria and Public Health}

In February 1997, Ian Wilmut announced he had cloned a lamb (Dolly) from the DNA of an adult sheep. ${ }^{92}$ In response to this startling development, President Bill Clinton asked his National Bioethics Advisory Commission (NBAC) to comment on the prospect of human cloning. In its report, the NBAC noted that Wilmut had made 277 embryos and produced only one lamb. If cloning were attempted in humans, "it would pose the risk of hormonal manipulation in the egg donor; multiple miscarriages in the birth mother; and possibly severe developmental abnormalities in any resulting child."93 Concluding that it was not yet safe to create a child through cloning, the NBAC recommended Congress enact a three to five year moratorium on such attempts until safety and ethical concerns could be resolved. ${ }^{94}$

In January 1998, an eccentric physicist named Dr. Richard Seed claimed he planned to clone babies. ${ }^{95}$ Even though Seed had no lab and was not a biologist, a media firestorm resulted. ${ }^{96}$ Shortly thereafter, Commissioner Michael Friedman announced that the FDA had the statutory authority to regulate reproductive cloning under the Food, Drug, and Cosmetic Act (FDCA) ${ }^{97}$ Any scientist interested in conducting clinical research would first have to file an investigative new drug (IND) application with the FDA. ${ }^{98}$

In October 1998, the FDA sent a warning letter to medical and research institutions. The FDA claimed clinical research to clone a human being was subject to its jurisdiction, but made clear it would deny any IND application due to "major unresolved safety questions." 99 Read in light of the NBAC report, the letter must have referred in part to the concern that cloned children could have developmental abnormalities.

The FDA soon extended its reach to another novel technology: nuclear transfer. Back in 1998, Doctors Jamie Grifo and John Zhang were inventing a

92. See Ian Wilmut ct al., Viable Offspring Derived from Fetal and Adult Mammalian Cells, 385 NATURE 810,810 (1997) (describing the scientific process of cloning).

93. National Bioethics Advisory Commission, Cloning Human Beings 65 (1997) [hercinafter NBAC REPORT].

94. See id. at 109 (recommending federal legislation to prohibit anyone from attempting to create a child through somatic cell nuclear transfer cloning for a time period of threc to five years).

95. See Valerie S. Rup, Human Somatic Cell Nuclear Transfer Cloning, the Race to Regulate, and the Constitutionality of the Proposed Regulations, 76 U. DET. MERCY L. REV. 1135, 1135 (1999) (explaining the intentions of Dr. Seed).

96. MACINTOSH, supra note 43 , at 82 . Dr. Secd has since sunk into obscurity. There is no cvidence that he ever came close to achicving his goal.

97. Richard A. Mcrrill \& Bryan J. Rose, FDA Regulation of Human Cloning: Usurpation or Statesmanship?, 15 HARV. J.L. \& TECH. 85, 87 (2001).

98. See MACINTOSH, supra note 43, at 82 (discussing the application process with the FDA regarding clinical research).

99. Letter from Dr. Stuart Nightingale, M.D., Associate Commissioner, Food and Drug Administration, Letter about Human Cloning (Oct. 26, 1998), available at http://www.fda.gov/oc/ohrt/irbs/irbletr.html. 
new means of giving infertile women in their forties the chance to have genetic children. ${ }^{100}$ Their strategy involved taking nuclei (and thus chromosomes) from the eggs of the infertile patients and transferring them into enucleated eggs from healthy young donors. ${ }^{101}$ This was not cloning; the eggs were fertilized with sperm following the nuclear transfer. The point was to give the infertile patients the benefit of the younger eggs ${ }^{102}$ and the fresh ooplasm inside them. That fluid contains mitochondria, structures that produce energy and facilitate embryonic development. ${ }^{103}$

Doctors Grifo and Zhang transferred reconstructed and fertilized eggs to two patients without achieving a pregnancy. They then presented their results at an ASRM meeting in October 1998. ${ }^{104}$ The media ran critical stories on the new method, which resembled cloning in that nuclear DNA was being transferred into an egg. ${ }^{105}$ Once alerted, the FDA claimed it had the authority to regulate nuclear transfer. ${ }^{106}$ Grifo had to end the research. ${ }^{107}$

Three years later, in 2001, the media reported that Dr. Panayiotis Zavos, an American fertility doctor, and Dr. Brigitte Boisselier, a scientist who belonged to a religious sect known as the Raelians, both had plans to clone babies. $^{108}$ These sensational reports fanned the flames of public sentiment against cloning and inspired the U.S. House of Representatives to hold extensive hearings on the matter. ${ }^{109}$ One influential witness was Dr. Rudolph Jaenisch, a biology professor at Massachusetts Institute of Technology. He claimed animal clones suffered from premature death and birth defects because the cloning process failed to "reprogram" the DNA used to create them. " ${ }^{10}$ In other words, the clones had all the genes they needed to develop, but some of those genes were not expressed properly. He asserted there probably were no "normal" animal clones.

100. Kate Johnson, First Human Pregnancy from Nuclear Transfer: Lasted Until 29 Weeks' Gestation (Dcc. 15, 2003), http://findarticles.com/p/articles/mi_m0CYD/ls_24_38/ai_11 2303392/?tag=content;coll .

101. Id.

102. Rick Weiss, Fertility Experiments Mix Genes of 2 Women, WASH. POST, Oct. 9, 1998, at A0I.

103. See MACINTOSH, supra note 43, at 23-24 (discussing the function of mitochondria).

104. Weiss, supra note 102.

105. See, e.g., id. at AI2 (explaining that "most researchers have said they arc adamantly opposed" to this procedure).

106. See Rick Weiss, U.S.-Banned Fertility Method Tried in China: Woman Became Pregnant Through Egg Transfer Technique but Lost All Three Fetuses, WASH. POST, Oct. 14, 2003, at AI0 (describing the ban imposed by the FDA).

107. Id. After the FDA shut them down, Grifo and Zhang shared their research on nuclear transfer with Chinese doctors. Id. The Chinese applied the method with a twist: fertilization with sperm was accomplished first, and transfer of the nuclear DNA to the donor egg came afterwards. Denise Grady, Pregnancy Created Using Egg Nucleus of Infertile Woman, N.Y. TIMES, Oct. 14, 2003, at AI, available at http://www.nytimes.com/2003/10/14/us/pregnancy-crcated-using-egg-nucleus-of-infertile-woman.html.A patient became pregnant with triplets but lost them one by onc to selective reduction, ruptured membranes, and infection. Id. The intended twins had no evidence of genetic defects. Id. The attending doctors belicve the bad outcome was due to the triplet pregnancy and not the nuclear transfer, but Chinesc authorities still banned the technique. $I d$.

108. MACINTOSH, supra note 43 , at 83.

109. See id. at 164 (discussing the media attention and Congressional action that followed the claims of Zavos and Boisselier).

110. Issues Raised by Human Cloning Research Before the Subcomm. on Oversight and Investigations of the Comm. on Energy and Commerce, 107th Cong. 44-46 (2001) (statement of Rudolph Jaenisch), available at http://frwcbgatc.access.gpo.gov/cgi-bin/getdoc.cgi?dbnamc=107_house_hearings\&docid=f:71495.pdf.

III. Id. 
Another key witness was Dr. Kathryn Zoon, Director of the Center for Biologics Evaluation and Research (CBER) at the FDA. She asserted that low success rates, abnormalities in offspring, and safety risks to mothers raised concerns about the use of cloning to clone a human being. ${ }^{112}$ Dr. Zoon claimed that the FDA had authority to control the use of cloning technology under the biologics provisions of the Public Health Service Act (PHSA) and the drug and device provisions of the FDCA. ${ }^{113}$ She assured lawmakers that the agency would deny permission to clone on safety grounds. ${ }^{114}$

Thereafter, the FDA immediately sent another wave of warning letters to research institutions and unleashed investigators upon Zavos and Boisselier, who moved their activities offshore. ${ }^{115}$

\section{Ooplasm Transfer: Dangerous Technology or Treatment for Middle-Aged Women?}

Meanwhile, Dr. Jacques Cohen of the Saint Barnabas Medical Center in New Jersey had pioneered a new technology known as ooplasm transfer. ${ }^{116} \mathrm{~A}$ doctor injects ooplasm from donor eggs into the infertile eggs of an older woman, along with sperm. ${ }^{117}$ The mitochondria in the donor ooplasm aid fertilization and proper embryonic development. ${ }^{118}$ Nearly thirty children have been born through this method worldwide. ${ }^{119}$

To infertile women, ooplasm transfer must have seemed a Godsend. From the FDA's perspective, however, it was a potential landmine. Here was another exotic technology that involved manipulation of cells and had the potential to grab headlines and irritate Congress.

In 2001, Dr. Zoon sent yet another round of warning letters to researchers (including fertility doctors). ${ }^{120}$ The FDA claimed it had jurisdiction over "human cells used in therapy involving the transfer of genetic material by means other than the union of gamete nuclei." 21 Examples included cell

112. Id. at 80 (statement of Kathryn C. Zoon).

113. Id.

114. Id. at $79-80$.

115. See MACINTOSH, supra note 43, at 83 (detailing how Zavos and Boissclier moved their rescarch outside the Unitcd Statcs).

116. See generally Jason A. Barritt ct al., Mitochondria in Human Offspring Derived from Ooplasmic Transplantation, 16 HUM. REPROD. 513, 513 (2001) (describing the procedurc developed by Dr. Cohen) [hercinafter Barritt I].

117. Id.

118. Id.

119. Id.

120. Letter from Kathryn C. Zoon, Dir. of the Ctr. for Biologics Evaluation and Rescarch, FDA, to Sponsors/Rescarchers, Human Cells Used in Therapy Involving the Transfer of Genetic Material by Means Other Than the Union of Gamete Nuclei, (July 6, 2001), available at http://www.fda.gov/ BiologicsBloodVaccincs/Saf ctyAvailability/ucm I 05852.htm.

121. Id. On what basis did the FDA exempt the union of ordinary sperm and eggs from the IND requirement? Dr. Zoon's letter stated that certain human cells, tissues, and cellular and tissuc based products (HCT/Ps) were regulated solely under regulations designed to prevent transmission of communicable discase and issucd pursuant to section 361 of the PHSA. See id. (citing 21 C.F.R. $§ 1271$ (2008)). These regulations provide that an HCT/P will be regulated solely under section 361 of the PHSA when certain criteria are met. Sperm and cggs that have becn minimally manipulated mect these criteria because they function as living cells and arc for reproductive usc. See 21 C.F.R. $\S 1271.10$ (a) (setting out the requirements for when section 361 of the PHSA will solcly regulate an HCT/P). The skeptical reader is left to wonder just how firm this excmption 
nuclei (used in cloning), oocyte nuclei (used in nuclear transfer), andooplasm containing mitochondrial genes (used in ooplasm transfer). ${ }^{122}$ Asserting that use of such genetically manipulated cells in humans required submission of an IND application, the letter cited a 1993 document in which the FDA had claimed authority over cell and gene therapy products. ${ }^{123}$

Since then, the FDA has identified three specific concerns about ooplasm transfer. First, children born through the method have a mix of mitochondria from both recipient and donor. ${ }^{124}$ This bothers the FDA because harmful mutations in mitochrondria can lead to disease. ${ }^{125}$ Second, two of eighteen fetuses conceived at Saint Barnabas had Turner syndrome (a genetic abnormality where one of the $\mathrm{X}$ chromosomes is missing); one miscarried and the other was aborted. ${ }^{126}$ Third, because ooplasm transfer mixes the mitochondria of two women in the reconstructed egg, it effects a genetic modification that the resulting child can pass on to future generations. ${ }^{127}$

But, on closer examination, the FDA's safety reasoning does nothold up. Ooplasm transfer need not lead to disease, for it mixes two healthy populations of mitochrondria. ${ }^{128}$ As for Turner syndrome, that is a chromosomal problem. The women treated with the donated ooplasm were older, and thus more likely to generate eggs with a missing $\mathrm{X}$ chromosome. ${ }^{129}$ If donated ooplasm improves the developmental potential of older eggs, it may generate more aneuploid embryos, but that problem is traceable back to the age-based infertility of the patients, rather than the technology involved. ${ }^{130}$ Nevertheless, now that the FDA has framed the issue as a matter of public health, it is unlikely to allow ooplasm transfer to proceed, even if the true problem is advanced maternal age.

\section{The FDA Asserts Questionable Authority to Regulate the Procreation of Infertile Men and Women}

To summarize, the FDA has blocked the use of reproductive cloning,

is, given that the agency retains the power to amend its own regulations.

122. Zoon, supra notc 120.

123. Id. (citing Application of Current Statutory Authoritics to Human Somatic Cell Therapy Products and Genc Therapy Products, 58 Fcd. Rcg. 53,248 (Oct. 14, 1993)).

124. See Barritt I, supra note 116, at 515 (documenting that ooplasm transfer children have mitochondrial DNA from two different women).

125. Biological Response Modifiers advisory Comm., Ctr. for Biologics Evaluation and Research, Food and Drug Admin., Dep't of Health and human Services, Open Session, Meeting \#32, 44-46 (May 9, 2002) [hercinafter BRMAC MEETING TRANSCRIPT], available at http://www.fda.gov/ OHRMS/DOCKETS/ac/02/transcripts/3855t1-01.pdf.

126. Id. at 46; See generally Jason A. Barritt ct al., Epigenetic and Experimental Modifications in Early Mammalian Development: Part Il Cytoplasmic Transfer in Assisted Reproduction, 7 HUM. REPROD. UPDATE 428, 429 (2001) [hercinafter Barritt II].

127. BRMAC MEETING TRANSCRIPT, supra note 125, at 42 ("In both cases heritable genetic modifications will be produced"); see also BIOLOGICAL RESPONSE MODIFIERS ADVISORY COMM., CTR. FOR Biologics Evaluation and Research, Food and Drug Admin., Dep't of Health and Human Services, BRMAC BRIEFING DOCUMENT FOR DAY 1, MAY 9, 2002: OOPLASM TRANSFER AS METHOD TO TREAT FEMALE INFERTILITY (asserting that genetic modification of eggs "crosses a line" by altering the genctic profile of unborn children), available at http://www.fda.gov/OHRMS/DOCKETS/ac/02/bricfing/3855B1_01.pdf.

128. Barritt I, supra notc I 16, at 515.

129. See Barritt II, supra notc 126, at 429-30 (discussing possible reasons for abnormalitics).

130. Id. 
nuclear transfer, and ooplasm transfer in the United States. Yet, there is a problem. The FDA can act only within the bounds of the statutory authority that Congress grants. The agency has been vague about the basis for its jurisdiction over cloning, nuclear transfer, and ooplasm transfer, stating only that it has jurisdiction over therapy involving gene transfer. ${ }^{131}$

Examining this claim more closely, one finds that the FDA long has claimed jurisdiction over clinical trials that transfer genes ${ }^{132}$ to existing persons in an effort to cure their genetic diseases. ${ }^{133}$ Such gene transfers have the same purpose and effect as drugs, making it plausible that the FDA has authority and can require an IND application. ${ }^{134}$

However, when it comes to cloning, nuclear transfer, and ooplasm transfer, the analogy to traditional drugs is extremely weak. Fertility doctors do not transfer somatic cell nuclei, egg nuclei, and ooplasm directly into patients. They transfer them into unfertilized eggs that are not human beings.

Perhaps the FDA thinks the embryo created from the somatic cell nuclei, egg nuclei, or ooplasm is a "drug" or "biological product" being supplied to the mother as patient. If so, the agency's statutory reasoning is erroneous. Even if we assume that the mother is infertile due to aging or dysfunctional eggs, cloning, nuclear transfer, and ooplasm transfer do not prevent, cure, or treat her disease. ${ }^{135}$ Rather, these novel methods of reproduction add a young egg donor as one of two (cloning) or three (nuclear or ooplasm transfer) biological parents. ${ }^{136}$

There is a third possibility, however, which deserves consideration. In 2003, two scholars from the Genetics and Public Policy Center argued that cloning was a drug because the somatic cell nucleus was an article intended to affect the structure or body of a future person, namely the cloned child. ${ }^{137}$ In

131. See supra text accompanying notes $121-23$.

132. Therapeutic gene transfer usually is accomplished by infecting a person with a specially-designed virus loaded with a normal gene. The virus releases the normal gene into malfunctioning target cells. The hope is that the new gene will make proteins that will help the target cells function properly. Other methods of gene transfer include liposome vectors, linking the gene to a molecule that binds to cell receptors, and directly introducing the genc to the cell. See generally U.S. Dep't of Energy Office of Sci., Human Genome Project Information: Gene Therapy, http://www.oml.gov/sci/tcchrcsources/Human_Gcnomc/medicine/ genetherapy.shtml (describing gene therapy).

133. See Merrill \& Rosc, supra note 97, at 118 (indicating the FDA has regulated gene therapy for scveral years).

134. Id.

135. See 21 U.S.C. $\S 321$ (g)(1) (2006) (defining "drug", by the FDCA, in part as an article intended "for use in the diagnosis, curc, mitigation, treatment, or prevention of disease in man"). See also 42 U.S.C. § 262(i) (2006) (defining similarly, by the PHSA, a "biological product" as any "virus, therapeutic scrum, toxin, antitoxin, ... or analogous product ... applicable to the prevention, treatment, or curc of a discase" or injuries of man).

136. See generally 21 U.S.C. $§ 321(\mathrm{~g})(1)$ (2006) (defining "drug," according to the FDCA, as also including articles intended to affect the structure or any function of the body of man). Although embryos created through cloning, nuclear transfer, and ooplasm transfer would affect the structure of a woman's body by making her pregnant, such embryos should not be considered drugs on this ground. The legislative history of the FDCA suggests that drugs must provide some health benefit for the person affected. See Merrill \& Rose, supra note 97, at 122 (drawing from the FDCA definition of "drug" an cmphasis on an inquiry into the intended use). Otherwise, as Professor Elizabeth Price Foley has noted, the FDA must have the power to requirc pre-market approval for all cmbryos, including those created through sexual intercourse and IVF. Elizabeth C. Pricc, Does the FDA Have Authority to Regulate Human Cloning? 11 HAR V. J. L. \& TECH. 619, 630,633 (1998).

137. See Gail H. Javitt \& Kathy Hudson, Regulating (For the Benefit of) Future Persons: A Different 
support of their claim that the FDA had a mandate to regulate for the benefit of future persons, ${ }^{138}$ the scholars relied on legislative history. Congress had amended the FDCA to require pre-market approval of drugs in response to the Thalidomide tragedy, in which a drug marketed to pregnant women to reduce nausea led to the birth of children without arms and legs. ${ }^{139}$

This theory has one clear advantage: by focusing on the child, it comes closest to addressing the concerns the FDA has about cloning, nuclear transfer, and ooplasm transfer. However, it fails to recognize one key distinction: when the FDA controls drugs such as Thalidomide that can cause harm when administered to a pregnant woman, it acts to protect an existing fetus. The FDA does not prevent the woman from reproducing; she is already in the process of doing so. Nor does the FDA seek to control the genetic characteristics of the eventual child; those have been determined at conception. Nor does the FDA attempt to judge or control the pattern of gene expression in the fetus; it allows that to emerge on its own during gestation.

By contrast, when the FDA prohibits cloning, nuclear transfer, and ooplasm transfer, it is acting to block the conception of children. This means that the FDA is deciding what genetic characteristics children are allowed to have. Under the FDA regime, children are not allowed to share DNA with another person (cloning), and they are not allowed to have mixed mitochondria that come from two different women (ooplasm transfer). Moreover, children are not allowed to exist if their gene expression might deviate from the norm, as is alleged to be the case with clones.

The ramifications are huge. First, by taking these technologies away from severely infertile men and women, the FDA is eliminating any chance they have to conceive genetic offspring. Second, by regulating to prevent the conception of children who might be flawed, the FDA is arrogating to itself the power to decide who is perfect enough to be born. The only protection it has to offer these children is the void of nonexistence. In the case of ooplasm transfer, it is also asserting authority to control the genetic profile of future generations.

The FDA appears to have stumbled into its new role as the reproductive police as a result of cloning politics. Congress never authorized the FDA to take on such a role, and it is wrong for the FDA to assume it. What the FDA is doing runs counter to our tradition of procreative autonomy ${ }_{141}^{140}$ and ignores public sentiment, which opposes coercive reproductive policies. ${ }^{141}$

Perspective on the FDA's Jurisdiction to Regulate Human Reproductive Cloning, 2003 UTAH L. REv. 1201, 1218 (2003) (cxplaining that "the transfer of a nucleus affects both the structure and function of the future individual. Morcover, the harms that have been posited with respect to human cloning will be experienced primarily, and perhaps entircly, by this future person.").

138. Id. at $1218-22$.

139. The scholars also cited FDA actions consistent with a presumption that the agency had the power to regulate on bchalf of future persons: requiring manufacturcrs to label drugs with information about effects on fetuses, regulating medical instruments employed during ART procedures, and asserting jurisdiction over ooplasm transfer. As the scholars themselves acknowledged, however, the mere fact that the FDA had taken these steps did not mean that it was acting within the statutory authority granted by Congress. Id. at 1222-27.

140. See Price, supra note 136, at 630 (arguing that Congress never intended the FDA to regulate the formation of human life and that federal power over the fundamental right to procreate should not be implicd).

141. See Paul A. Lombardo, Taking Eugenics Seriously: Three Generations of ??? Are Enough?, 30 FLA. 


\section{B. The President's Council on Bioethics}

In 2001, former President George W. Bush created a President's Council on Bioethics (Council) to report on bioethical issues in biomedical science and technology. ${ }^{142}$ The man he appointed to head the Council was Dr. Leon Kass, a long-time opponent of IVF. ${ }^{43}$ Though President Barack Obama has since disbanded the Council, ${ }^{144}$ its reports could have a lasting impact on public policy and must be taken seriously.

One of the Council's first actions was to issue a report entitled Human Cloning and Human Dignity: An Ethical Inquiry. ${ }^{145}$ The report concluded that it was too risky to clone at the present time, ${ }^{46}$ and called upon Congress to ban reproductive cloning. ${ }^{147}$ More dramatically, it asserted there was no ethical way to make cloning safe, now or in the future. ${ }^{148}$ Animal experiments might not predict risks to humans, and a cloned child could not consent to the experiment. ${ }^{149}$

But, the Council did not stop with cloning. It insinuated that the first IVF attempts had also been unethical experiments upon the unborn, ${ }^{150}$ and cited the Hansen study to suggest that IVF and ICSI might be unsafe for children today. ${ }^{151}$ And, at the end of its report, the Council expressed the need to undertake a comprehensive review of conventional ART, claiming little was known about the risks involved. ${ }^{152}$

In 2004 this dark seed blossomed into a new report entitled Reproduction \& Responsibility: The Regulation of New Biotechnologies. ${ }^{153}$ The report covered a variety of technologies ranging from stem cell research to genetic engineering. ${ }^{154}$ However, the Council chose ART as its starting point, in part

ST. U. L. REv. 191, 216 (2003) ("[G]ovemmental involvement in coercive reproductive policies is the most objectionable feature of cugenics to most people today.").

142. Exec. Order No. 13,237, 66 Fed. Reg. 59,851 (Nov. 30, 2001).

143. At a 1971 symposium on medical ethics, Kass excoriated Robert Edwards and his partner, Patrick Steptoc, who were then in the process of perfecting IVF. Speculating that IVF could deform babies, Kass wamed that prenatal testing could not assure a good outcomc. ROBERT EDWARDS \& PATRICK STEPTOE, A MATTER OF LifE: The STORY OF A MEDICAL BREAKTHROUGH 11-15, 112-13 (1980). But Edwards and Steptoc forged ahead, and the subsequent birth of a healthy baby girl named Louise Brown in 1978 seemed to prove Kass wrong. Mark D. Eibert, Human Cloning: Myths, Medical Benefits and Constitutional Rights, 53 HASTINGS L.J. 1097, 1103 (2002)

144. Nicholas Wade, Obama Plans to Replace Bush's Bioethics Panel, N.Y. TIMES, June 18, 2009, at A24.

145. President's Council on Bioethics, human Cloning and Human Dignity: An Ethical INQUIRY (2002).

146. Id. at $89-90$.

147. Id. at 205.

148. Id. at 94 ("There seems to be no ethical way to try to discover whether cloning-to-produce-children can become safe, now or in the future.").

149. See id. at 92-94 (describing the moral concems and practical limitations inherent in any attempt to devclop human cloning).

150. See id. at 93 (noting that the success of IVF attempts did not automatically make the attempts themselves ethical).

151. See id. (citing the Hansen study, which found the major defects associated with IVF and ICSI were cardiovascular, musculoskcletal, chromosomal, and urogenital in nature).

152. See id. at 211 (concluding that a moratorium on cloning and related research should be declared until an extensive review of the practices could be conducted).

153. REPRODUCTION AND RESPONSIBILITY, supra note 61.

154. Id. 
due to concern for the safety and well-being of children. ${ }^{155}$

After describing available ART and success rates, the Council turned to ethical considerations, in particular the well-being of children. It reviewed the existing literature and raised the following concerns.

ART children might be twice as likely to suffer major birth defects. ${ }^{156}$ ICSI could allow men to pass genetic abnormalities (including chromosomal deletions that cause male factor infertility) to children. ${ }^{157}$ ICSI might be associated with an increased rate of chromosomal abnormalities and mental developmental delays. ${ }^{158}$ Culture media, duration of culture, and cryopreservation of embryos could harm children by affecting gene expression or shortening telomeres. ${ }^{159}$ Multiple gestations placed children at risk of premature birth and low birth weight, and even singletons might face these risks. ${ }^{160}$

The Council surveyed existing regulation ${ }^{161}$ and concluded the patchwork of federal, state, and private oversight was inadequate to address its ethical concerns, particularly the safety and well-being of children. ${ }^{162}$ However, it stopped short of recommending immediate enactment of new legislation or regulation. Instead, it claimed that more information was needed, particularly on the health of children conceived through ART. ${ }^{163}$ Thus, it recommended the federal government fund a prospective longitudinal study of the impact of ART on the health of children. ${ }^{164}$

The Council also recommended doctors treat children to be born through ART as their patients. ${ }^{165}$ The doctors should cooperate with researchers studying the health impacts of ART, take steps to reduce the rate of multiple embryo transfers and births, and extend human subject protections to embryos whenever research or innovative clinical interventions could affect the health and welfare of resulting children. ${ }^{166}$

Though these recommendations may seem modest, one should not underestimate them. As we have seen, the FDA has halted cloning, nuclear transfer, and ooplasm transfer on safety grounds. ${ }^{167}$ Taken together with the

155. See id. at 3-4 (discussing the scope of the inquiry and its reasons for focusing upon ART).

156. See id. at 38 (citing the Hansen study discussed above in the text accompanying notes 78-79).

157. See, e.g., Page et al., supra notc 39 at 1725 (showing that men with infertility caused by a genc delction can have sons by ICSI but are likcly to transmit the deletion and infertility to their sons).

158. See REPRODUCTION AND RESPONSIBILITY, supra note 61, at 39-40 (citing scveral studics linking ICSI to genctic and developmental defects).

159. See id. at 40 (citing studics addressing the risks associated with ART and freczing of cmbryos).

160. See id. at 41 (addressing the dangers faced by ART children during gestation).

161. See id. at 46-75 (discussing statc and federal regulations of ART cxtensivcly).

162. Id. at $75-78$.

163. See id. at 205-06 ("Wc do not accuratcly know, for example, how the technologics and practices at the heart or our inquiry affect the health of those whose lives are touched by them-most notably, the children conccived with their aid.").

164. Id. at 208-09.

165. Id. at 215. At an carlicr point in the report, the Council criticized ASRM guidelines for relying on infertile men and women to safeguard the interests of their prospective children without making allowance for conflict of interest. $I d$. at 78 . Curiously, the Council secmed not to realize that if infertile adults and their prospective children are indecd in conflict, having fertility doctors treat both as patients could create a conflict of interest for the doctors.

166. Id. at $215-17$.

167. See Judith A. Johnson, Cong. Research Serv., RS 21096, Human Cloning 5 (2001) (“The Food 
Council report, these developments are signposts on the road to a future in which federal and state governments use data acquired from studies as a rationale for restricting access to IVF and ICSI on safety grounds.

Moreover, the Council report has set the stage for increased governmental intervention. The choice of child welfare as the touchstone, the lengthy recital of studies suggesting negative health impacts, and the criticism of industry self-regulation all point to the need for governmental control over ART, even if the Council did not quite have enough data to support that recommendation. Certainly the Council anticipated that further research would lead to such a conclusion:

The need seems clear for more data to determine what risks, if any, different assisted reproduction techniques present to the well-being of the future child. Moreover, in cases where ART is the only available means for individuals or couples to conceive a biologically related child, it is an important ethical and social question what level of increased risk can be privately justified by patients and doctors, and what level of increased risk should be publicly justified by society as a whole, especially should the society bear the costs of caring for any resulting health problems. ${ }^{168}$

\section{ART AND SAFETy: ThE LATEST StUdiES}

Five years have passed since the Council called for more data. What have we learned from the latest medical studies? Is it true that ART is unsafe for children?

To answer these questions, this Part reviews medical studies that compare ART children ${ }^{169}$ with spontaneously conceived children in order to determine whether the former face increased risk. Three categories of health problems will be considered: (1) major birth defects; (2) rare disorders; and (3) poor outcomes during the critical "perinatal" period immediately before and after birth, such as premature birth and low birth weight.

\section{A. Birth Defects}

Around 3\% of newborn infants in the United States have a major defect that can be detected at birth. ${ }^{170}$ Do children conceived through ART have a

and Drug Administration (FDA) has sent letters to the rescarch community stating that the creation of a human being using cloning is subject to FDA regulation under the Public Health Service Act and the Food, Drug and Cosmetic Act."). See also Ctr. for Genetics and Soc'y, Ooplasmic Transfer (Mar. 30, 2003), http://www.geneticsandsociety.org/article.php?id=381 ("A general consensus was reached at the meeting that more preclinical data would be necessary before FDA would allow further clinical trials involving ooplasm transfer to proceed.").

168. REPRODUCTION AND RESPONSIBILITY, supra note 61 , at 42 (cmphasis added).

169. Though most of the studies in this Part focus on children conceived through IVF, some include of fspring of GIFT and ZIFT. These methods arc similar to IVF in that they involve ovulation stimulating drugs and the handling of sperm and eggs outside the body. Also, in some studies IVF children may have been conceived through ICSI.

170. Shai E. Elizur, M.D. \& Togas Tulandi, M.D., M.H.C.M., Drugs in Infertility and Fetal Safety, 89 FERTILITY \& STERILITY 1595, 1595 (2008). 
higher rate of major birth defects? ${ }^{171}$

In 2005, Tracy Shevell and an American research consortium reported the results of a prospective study of singletons conceived through IVF and other ART. $^{172}$ This team found no increased rate of chromosomal or structural abnormalities compared with spontaneously conceived controls. ${ }^{173}$ These results were consistent with those in many earlier studies. ${ }^{174}$

However, other recent studies show that singletons are 1.3 to 1.5 times more likely to have a birth defect if conceived through IVF and other ART. ${ }^{175}$ If these studies are correct, and the rate of major birth defects in the general population is $3 \%$, then $4-4.5 \%$ of IVF singletons could be expected to have such defects.

What kind of birth defects do ART singletons have? In 2009, CDC researchers reviewed six years of data from the National Birth Defects Prevention Study. They found 230 women who conceived through ART and bore a child with a major birth defect. ${ }^{176}$ Compared with spontaneously conceived babies, the ART singletons had 2.1 times the risk of septal heart defects (i.e., gaps in the muscle wall between the atrial or ventricular heart chambers). ${ }^{177}$ They also had 2.4 times the risk of cleft lip and palate, 4.5 times

171. In general, a "major birth defect" is an anatomical defect that requires treatment or impairs function. Rolv T. Lie ct al., Birth Defects in Children Conceived by ICSI Compared with Children Conceived by Other IVF-Methods; A Meta-Analysis, 34 INT'L J. EPIDEMIOLOGY 696, 697 (2004). Some rcscarchers categorizc def ects according to an cstablished system, but there arc more than onc. Compare Christinc K. Olson et al., In Vitro Fertilization Is Associated with an Increase in Major Birth Defects, 84 FERTILITY \& STERILITY 1308, 1310 (2005) (applying CDC guidclincs), with Jin Liang Zhu ct al., Infertility, Infertility Treatment, and Congenital Malformations: Danish National Birth Cohort, 333 BMJ 679, 680 (2006) (cmploying Intcrnational Classification of Discascs, 10th revision, with some adjustments).

172. See Tracy Shcvell, M.D. ct al., Assisted Reproductive Technology and Pregnancy Outcome, 106 OBSTETRICS \& GYNECOLOGY 1039, 1039 (2005) (giving the results of a study on the effects of ART). Most studies control at least for maternal age and parity. This study madc a Herculcan effort to adjust data to control for multiple confounders, such as age, race, marital status, education, preterm deliveries or fetal anomalics in prior pregnancies, body mass index, smoking history, and blecding during gestation. See id (listing the confounders this study adjusted for).

173. Id.

174. See supra studies citcd note 79

175. See, e.g., Michćle Hansen ct al., Assisted Reproductive Technologies and the Risk of Birth DefectsA Systematic Review, 20 HUM. RePROD. 328, 334 tbl. V (2005) (reporting 1.3I to 1.35 timcs more likcly); Olson et al., supra note 171, at 1311 tbl. 3 (2005) (reporting 1.44 times more likely); Alfred A. Rimm et al., $A$ Meta-Analysis of Controlled Studies Comparing Major Malformation Rates in IVF and ICSI Infants with Naturally Conceived Children, 21 J. Assisted REPROD. \& GENETICS 437, 441 tbl. II (2004) (reporting 1.51 times more likely). See also Zhu ct al., supra note 171, at 680 tbl. I (reporting 1.39 times the risk for offspring of all fertility treatments: IVF, ICSI, intrauterine insemination, hormonal treatment, surgery, hysterosalpingography, and alternative treatments such as acupuncture).

176. J. Reefluis ct al., Assisted Reproductive Technology and Major Structural Birth Defects in the United States, 24 HUM. REPROD. 360, 362 (2009).

177. See id. at 360 (reporting a 2.1 adjustcd odds ratio for septal heart defects); accord, Olson ct al., supra note 171, at 1312 tbl. 4 (finding more than double the rate of cardiovascular defects among IVF infants, including septal heart defects). Septal heart defects arc common, occurring in one out of 100 newborns in the general population. These gaps often close as an infant grows. The rest can be corrected through surgery. See If Your Child Has a Heart Defect, KIDS HEALTH, http://kidshealth.org/parent/systcm/ill/if heart_defect.html (last visited Sept. 19, 2010) (discussing congenital heart defects in children). Therefore, some ART researchers believe they should not be classificd as major abnormalitics. See Retzloff \& Hornstein, supra note 79 , at 854-55 (disagrccing with a study that classificd cardiac malformations as major abnormalitics). Moreover, the level of serutiny an infant receives may determine whether a septal heart defect is detected. The CDC attempted to correct for this by adjusting data for family income and demographic factors. Recfhuis et al., supra note 176, at 365 . However, when parents or pediatricians know a child was conceived through 
the risk of esophageal defects, 3.7 times the risk of anal and rectal defects, and 2.1 times the risk of hypospadias. ${ }^{178}$ The results of this study have received widespread media attention. ${ }^{179}$

What about twins and other multiples? Because multiples must share maternal resources, they tend to have a higher rate of birth defects than singletons. For example, one study found spontaneously conceived twins were 1.38 times more likely to have a major birth defect than spontaneously conceived singletons; for triplets and higher-order multiples, the risk nearly doubled. ${ }^{180}$

Multiple embryo transfer increases a woman's odds of bearing multiple babies. ${ }^{181}$ However, when compared with spontaneously conceived multiples, IVF multiples show no or minimal increase in the risk of birth defects. ${ }^{182}$ In other words, though multiples conceived through any means are more likely to have birth defects than singletons are, being conceived through ART does not appear to heighten the risk for multiples any further.

This observation raises an apparent contradiction in the data. How can ART multiples not face an increased risk of birth defects when many studies show that ART singletons do? The answer could lie in study design. Monozygotic (identical) twins have a higher rate of complications than dizygotic (fraternal) twins ${ }^{183}$ and occur more of ten among spontaneously conceived infants. ${ }^{184}$ Thus, studies comparing IVF multiples with spontaneously conceived controls could mask an increase in risk of birth defects associated with IVF. ${ }^{185}$ However, researchers have not yet substantiated this theory. ${ }^{186}$

technological means, they may be more vigilant, leading to increased detection of septal heart defects.

178. See Recfluis et al., supra note 176, at 360 (summarizing the results of the study). Hypospadias is a male condition in which the urethral opening is located in the wrong place-for example, on the underside rather than the tip of the penis. It can be corrected with surgery. See CARING FOR YOUR BABY AND YOUNG CHild, BIRTH TO AgE 5 606-07 (Steven P. Shelov \& Robert E. Hannemann cds., rev. ed. 1998) (discussing hypospadias and its treatments). Hypospadias is a relatively common birth defect, occurring in three to four out of 1000 births in the general population. Suzan L. Carmichacl ct al., Maternal Progestin Intake and Risk of Hypospadias, 159 ARCHIVES OF PEDIATRIC \& AdOLESCENT MED. 957, 962 (2005).

179. See, e.g., Gina Kolata, Picture Emerging on Genetic Risks of IVF, N.Y. TIMES, Feb. 17, 2009, at DI, available at http://www.nytimes.com/2009/02/17/hcalth/1 7ivf.html?_r=1\&pagewanted=all (recognizing studics associating "abnormal patterns of genc expression" with IVF).

180. Olson ct al., supra note 171, at 1312. See also Wci Cui ct al., Sex Differences in Birth Defects: A Study of Opposite-Sex Twins, 73 BirTh DefeCrs Res. (Part A): Clinical and Molecular Teratology 876,876 (2005) (giving population data from Florida Birth Defects Registry showing $4.72 \%$ of malc and $3.67 \%$ of femalc twins have birth defects).

181. See supra text accompanying notes 74-76.

182. See, e.g., Sarah McDonald ct al., Perinatal Outcomes of In Vitro Fertilization Twins: A Systematic Review and Meta-analyses, 193 AM. J. OBSTETRICS \& GYNECOLOGY 141, 147 tbl. VII (2005) (summarizing "key perinatal outcomes from case-control studics of IVF twins"); Recfluis et al., supra note 176, at 362; Rimm ct al., supra note 175, at 442.

183. Two-thirds of monozygotic (identical) twins share a monochorionic placenta. NANCY L. SEGAL, Entwined lives: Twins and What They Tell Us About Human Behavior 13-14, 22 (1999); Kurt Benirschkc, The Biology of the Twinning Process: How Placentation Influences Outcome, 19 SEMINARS in PERINATOLOGY 342, 346 (1995). Monozygotic twins who share a monochorionic placenta have a significantly increased rate of perinatal complications. McDonald et al., supra note 182, at 149.

184. Monozygotic twins account for onc-third of all spontancously conccived twins, but only $2 \%$ of IVF twins. McDonald ct al., supra note 182, at 149.

185. Recfluis et al., supra note 176, at 363; Rimm et al., supra note 175, at 442.

186. A recent Australian study compared ART twins with spontancously conceived boy-girl twins 


\section{Is Technology to Blame?}

Since some studies have found an increased risk of major birth defects, the next challenge is to identify the cause. Do these defects originate in some feature of assisted reproductive technologies themselves?

Some writers speculate that the ovarian stimulation protocol used during IVF cycles might disrupt the uterine environment, alter pre-implantation embryonic development, or recruit chromosomally abnormal eggs that otherwise would not have matured. ${ }^{187}$ However, a recent survey of the literature on fertility drugs found no current evidence that gonadotropins cause birth defects. ${ }^{188}$ The gonadotropin releasing hormone agonists used to downregulate the pituitary gland also appear to be safe. ${ }^{189}$ As for progestins (used to prepare the uterus for implantation and pregnancy), most studies showed no link to birth defects aside from an increased rate of hypospadias in baby boys. 190

Another common speculation is that defects result when the basic IVF process is enhanced through ICSI, the process whereby a lab technician injects sperm into eggs to achieve fertilization. ${ }^{191}$ Some have worried that this technique may enable fertilization when either sperm or eggs have chromosomal or structural abnormalities or are of poor quality. ${ }^{192}$ In addition,

(presumed to be dizygotic). With monozygotic twins removed from the control population, the ART twins had 1.4 times the risk of birth defects. However, the researchers did not consider this increased risk to be statistically significant. Michèle Hansen et al., Twins Born Following Assisted Reproductive Technology: Perinatal Outcome and Admission to Hospital, 24 HUM. REPROD. 2321, 2323 tbl. I, (2009) (hereinafter Hansen II). Similarly, a Swedish study that also used spontancously conceived boy-girl twins as controls found IVF twins had only 1.1 times the rate of birth defects. A. Ericson \& B. Källén, Congenital Malformations in Infants Born after IVF: A Population-Based Study, 16 HUM. REPROD.504, 506 (200I).

187. See, e.g., Robert M. L. Winston \& Katc Hardy, Are We Ignoring Potential Dangers of In Vitro Fertilization and Related Treatments?, FerTILITY SuPPLEMENT, NATURE CEll BIOlOGY \& NATURE MED. S14, SI5 (2002) ("[I]mplantation may be more likely when large amounts of exogenous gonadotropins are avoided.").

188. The authors noted that the research on this point was older and should be updated. See Elizur \& Tulandi, supra note 170, at 1600 ("There is no or minimal risk of congenital malformation associated with .. . gonadotropin .... Nevertheless, most studies evaluating the possible relationship between birth defect and gonadotropin were in the 1980s and carly 1990s.").

189. Id. at 1599. The authors did find problems with a different drug sometimes uscd to stimulate ovulation in infertile women. Clomiphene citrate has a chemical structure similar to dicthylstilbestrol (DES), a well-known teratogen. Some data associate clomiphene citrate with a slightly elevated risk of neural tube defects, and a six-fold increase in severe hypospadias in boy babies. Id. at 1595-96. However, this drug does not stimulate the ovaries as powerfully as gonadotropins and is not commonly used as part of IVF cycles.

190. Id. at 1598-99. One study found that the use of progestin during the first trimester of pregnancy was associated with 3.7 times the risk of bearing a son with moderate or severe hypospadias. Carmichacl ct al., supra note 178, at 959-60. Mothers who underwent no fertility treatments beyond progestin still had twice the risk of producing a son with hypospadias, suggesting that the drug itsclf was to blame. Id. at 960 . However, one weakness of this study is that the rescarchers did not have direct information about the infertility of the parents (such as the time to conception), and so could not account for that confounder. Id. at 961 .

Another study (not cited in the Elizur \& Tulandi survey) showed a more dramatic five-fold increase in the risk of hypospadias for IVF infants. However, this data was not adjusted for matemal age. See Richard I. Silver et al., In Vitro Fertilization Is Associated with an Increased Risk of Hypospadias, 161 J. UROLOGY 1954, $1955-$ 56 (1999) (finding a five-fold risk of hypospadias for male IVF infants, but noting that maternal age was unavailablc for the control group).

191. See, e.g., Winston \& Hardy, supra note 187, at S17 ("Most reports concerning ICSI were fairly encouraging, although a re-classification of cases from a large series suggested that the incidence of major defects had been under-cstimated.").

192. See Retzloff \& Homstein, supra note 79, at 852 ("[T]here is the potential for incorporating sperm 
the injection process could contaminate the egg with foreign substances or disrupt its structure. ${ }^{193}$ But, studies of birth defects do not point to ICSI as the culprit. For example, in 2004, American researchers conducted a metaanalysis of nineteen studies and found that ICSI singletons had 1.33 times the risk of major malformations. ${ }^{194}$ This falls within the 1.3-1.5 range found in recent studies of IVF singletons, ${ }^{195}$ suggesting that ICSI may not add much risk beyond that already associated with IVF. ${ }^{196}$

Cryopreservation of spare embryos also has been cited as a potential risk to children who may later be born from those embryos. ${ }^{19}$ However, Scandinavian doctors recently reviewed the medical literature and concluded children had comparable rates of birth defects whether born from fresh or frozen embryos. ${ }^{198}$

\section{Infertility as the Root Cause}

There is another possibility: the increased risk of birth defects observed in children of ART may be related to the underlying physiologic characteristics of infertile parents.

More than half of all ART cycles using fresh embryos made from the patient's own eggs involve women who are thirty-five or older. ${ }^{199}$ Advanced maternal age is strongly linked with not only infertility but also chromosomal abnormalities in offspring. ${ }^{200}$ Of course, scientists who study birth defects

mitochondrial DNA or fertilizing anomalous female gametes that would otherwise be bypassed by natural sclection.").

193. Id

194. Rimm et al., supra note 175 , at 441 tbl. II.

195. See supra text accompanying note 175.

196. This meta-analysis was not ideal because some of the IVF studies included ICSI babies in their sample set. This overlap could inflate the rate of birth defects in the IVF studies, making it appear more similar to the rate in ICSI studies. However, two other studies have reached similar conclusions. A team of German scientists studied more than 3000 ICSI babies and found they were 1.24 times more likely than spontancously conceived controls to have major congenital malformations. Alexander Katalinic et al., Pregnancy Course and Outcome After Intracytoplasmic Sperm Injection: A Controlled, Prospective Cohort Study, 81 FERTILITY \& STERILITY 1604, 1604 (2004). A Norwegian meta-analysis found that IVF performed with ICSI was associated with only 1.12 times the risk of major birth defects as IVF alone. Lic et al., supra note 171. In addition, ICSI children have been closely examined for developmental issues. Toddlers have been shown to have normal neurological development. See AG Sutcliffe et al., Outcome in the Second Year of Life After In-vitro Fertilisation by Intracytoplasmic Sperm Injection: A UK Case-Control Study, 357 LANCET 2080, 2080 (2001) (finding little or no difference between ICSI children and children of a control group in mental development). Five-year olds have been found to have cognitive and motor skills comparable to spontaneously conceived children. I. Ponjacrt-Kristoffersen et al., International Collaborative Study of Intracytoplasmic Sperm Injection-Conceived, In Vitro Fertilization-Conceived, and Naturally Conceived 5Year-Old Child Outcomes: Cognitive and Motor Assessments, 115 PEDIATRICS c283, e283 (2005)

197. See REPRODUCTION AND RESPONSIBILITY, supra note 61, at 40 ("Cryopreservation might affect gene expression or lead to other molecular effects ....").

198. See U.B. Wennerholm et al., Children Born After Cryopreservation of Embryos or Oocytes: A Systematic Review of Outcome Data, 24 HUM. REPROD. 2158, 2169 (2009) ("Data concerning infant outcome [for children born from frozen embryos] scems reassuring with even higher birth weights and lower rates of preterm and low birth weights than children born after fresh IVF/ICSI."). Similarly, children conceived with frozen donor sperm do not have increased rates of birth defects. See J. Lansac \& D. Royère, Follow-up Studies of Children Born After Frozen Sperm Donation, 7 HUM. REPROD. UPDATE 33, 34-35 (2001) (finding no significant difference in overall prevalence of birth defects).

199. 2007 ART REPORT, supra notc 74, at 58.

200. See supra text accompanying notes 15-18 (discussing the risks of advanced maternal age). 
realize the importance of maternal age; most provide age-matched controls or adjust data to account for chronological age. However, they may still be comparing apples and oranges.

As discussed in Part I.A, what matters most is ovarian reserve, which reflects biological age. Women thirty-five and older who are able to conceive on their own may have better-than-average ovarian reserve, while infertile patients in the same age group may have worse-than-average ovarian reserve. If so, age-matched controls will be mismatches, and chronological adjustments to data will be inaccurate, causing studies of birth defects to overstate the risk that ART presents.

Moreover, we know that infertile men and women are more likely to produce aneuploid eggs and sperm. Resulting embryos that bear the wrong number of chromosomes will often miscarry but sometimes grow into children with Down syndrome and the like. ${ }^{201}$ Infertile men and women are also more likely to have major structural chromosomal abnormalities that can produce faulty gametes and children with unbalanced translocations and severe birth defects. $^{202}$

Such gross chromosomal abnormalities are the tip of an iceberg that scientists are just beginning to explore. Some believe infertility also results from more subtle structural chromosomal abnormalities, genetic mutations, and epigenetic anomalies. ${ }^{203}$ These problems are carried in sperm and eggs and can disrupt the development of unborn children. ${ }^{204}$

For example, German researchers Bernhard Horsthemke and Michael Ludwig have suggested that developmental pathways are ordinarily robust enough to produce organisms with the standard "phenotype" (body and other visible characteristics) even if the organism incorporates minor genetic variation or has been subjected to changes in its environment. ${ }^{205}$ This could explain why "the vast majority of children conceived by assisted reproduction technology (ART) are healthy, although ART bypasses a lot of biological filters such as selective gamete resorption, selective sperm uptake, sperm competition and selective syngamy, and subjects the gamete and early embryo to environmental stress (hormones, culture media and physical stress). ${ }^{, 206}$

At the same time, there is enough plasticity in development to allow organisms to respond to environmental stressors with epigenetic changes that generate modified phenotypes. ${ }^{207}$ Horsthemke and Ludwig theorize that infertile men and women have genes that predispose them to produce epigenetically unstable gametes. This makes their embryos more vulnerable to

201. See supra text accompanying note 14 (stating that three 21 chromosomes oft en leads to miscarriage, but may result in a child with Down syndrome).

202. See supra tcxt accompanying notes 31-35 (discussing risks of structural chromosomal abnormalitics).

203. See supra Part I.A.2 and .3 (discussing these potential infertility causes).

204. Id.

205. Horsthemke \& Ludwig, supra note 53, at 473.

206. Id.

207. See id. at 473-74 ("[D]cvelopmental plasticity provides organisms with the ability to develop a certain range of phenotypes in response to environmental cues. Such cues probably affect gene expression by inducing epigenetic changes."). 
epigenetic changes, whether conceived through ART or not. ${ }^{208}$ Once epigenetic control is lost, the embryo may develop incorrectly or reveal genetic variations that result in birth defects. ${ }^{209}$

Given the importance of chromosomal, genetic, and epigenetic factors, studies that compare children of ART born to infertile parents with spontaneously-conceived controls born to fertile parents are likely to mislead because they entangle two issues: infertility and technology. ${ }^{210}$

To find out whether ART causes birth defects, researchers would have to recruit fertile men and women who already have healthy children and ask them to conceive more children using the technology. ${ }^{211}$ But, fertile men and women do not use ART, and have no incentive to undergo the pain, expense, and putative risk of treatment. Therefore, it is not possible to design the ideal study. $^{212}$

Nevertheless, researchers are striving to design experiments with better, if not ideal, controls. ${ }^{213}$ For example, Jin Liang Zhu and colleagues examined the Danish national birth cohort from 1997 to $2003 .^{214}$ Singletons born to infertile couples who underwent fertility treatment had a $6.7 \%$ birth defect rate, which is 1.39 times the $5 \%$ rate observed in singletons born to fertile couples. $^{215}$ That falls within the range noted in recent articles that have run similar comparisons. ${ }^{216}$

However, Zhu and his team added a new twist to the research. They also studied singletons born to infertile couples who conceived naturally, but after more than twelve months. ${ }^{217}$ Compared with singletons born to fertile couples, the offspring of infertile couples were more likely to be born with birth defects, even when no fertility treatments were involved. ${ }^{218}$

The team did not stop there. It directly compared singletons of treated and untreated infertile couples. ${ }^{219}$ Those born to the treated couples were only 1.17 times more likely to have a birth defect than those born to the untreated couples. $^{220}$ In other words, once children of infertile parents were chosen as

208. Id. at 473 .

209. See id. at 479-80 (noting loss of epigenetic control may change "development trajectorics and/or expose hidden genetic variance").

210. See Jcan Cohen, Infertile Couples, Assisted Reproduction and Increased Risks to the Children, 15 REPROD. BIOMEDICINE ONLINE 245, 246 (2007) (noting lack of control groups results in difficulty distinguishing betwecnassisted reproductive treatment and underlying fertility).

211. See id. (suggesting lack of control groups causes research issues).

212. See id. (suggesting enough issues may arise to negate the possibility of an ideal study).

213. See id. (noting organizations could promote ideal studics).

214. See Zhu ct al., supra note 171 at 679-81 (describing a study of threc groups of live born children and their mothers).

215. Id. at 680 tbl. I. For purposes of this study, fertility treatments included IVF, ICSI, intrauterine insemination, horrnonal treatment, and surgery. See id. at 680-88 (noting comparisons between these methods and fertile couples).

216. See supra text accompanying note 175 . Studies show that singletons are 1.3 to 1.5 times more likely to have a birth defect if conceived through IVF and other ART. Id.

217. Zhu ct al., supra note 171 , at 679 .

218. Id. at 680 .

219. Id. at 679 .

220. Id at 680 tbl. I. The only specific risk that more than doubled was that of genital organ malformations. Id. This outcome could indicate a drug effect, $i d$. at 681 , but could also reflect the more severe infertility of the treated couples. See Retzloff \& Hornstcin, supra notc 79, at 856 (noting that hypospadias is linked to paternal infertility); Silver et al., supra note 190, at 1956 (explaining that hypospadias runs in 
controls, there was a big drop in the risk associated with treatment. This implies that infertility itself is a risk factor for having children with birth defects. $^{221}$ Indeed, the $17 \%$ increase in risk for the singletons of treated couples could be associated with infertility severe enough to require medical assistance, rather than treatment as such. ${ }^{22}$

Similarly, in 2005, Christine Olson and a team of researchers studied children conceived and born in Iowa. ${ }^{223}$ The team found 1.44 times the risk of major birth defects in IVF singletons. ${ }^{224}$ Within the IVF group, use of ICSI, embryo freezing, and length of culture did not affect the birth defect rate. This led the researchers to suggest that the problem "might be inherent in the infertile couples or secondary to ovulation induction.,"225 However, children conceived through intrauterine insemination (IUI) following ovulation induction faced only 1.19 times the risk, ${ }^{226}$ so drugs alone could not account for the IVF results. Again, the rate of birth defects might rise along with the severity of the underlying infertility. ${ }^{227}$ Since IVF is so expensive, patients usually do not pursue it until less invasive methods like IUI have already failed. ${ }^{228}$

An earlier paper had results that were even more striking. In 2001, Erickson and Kallen published a study of over 9000 infants conceived through IVF and born in Sweden during the period 1982-1997. ${ }^{229}$ Raw data showed that children conceived through IVF had 1.47 times the risk of major and minor congenital malformations. ${ }^{230}$ Following adjustment for maternal age, parity, and plurality, IVF singletons still faced 1.24 times the risk. ${ }^{231}$ However, once the data were adjusted for years of involuntary childlessness, the IVF singletons actually had a lower risk of congenital malformations than infants in the general population. ${ }^{232}$

Why does this matter? Lawmakers and regulators might react differently if the problems observed in children are related to characteristics of the parents, as opposed to ART as such. Those who feel comfortable attacking "unsafe" technologies may shrink away from restricting ART in order to keep infertile men and women from having children.

familics and also is more common in the of fspring of mothers older than forty years).

221. See Olson ct al., supra note 171, at 1313 (suggesting that genetic problems in parents could impair infertility and cause birth defects in children).

222. See Zhu et al., supra note 171, at 682 (conceding that untreated infertile couples might differ from treated infertile couples in type or degree of infertility).

223. Olson ct al., supra note 171 , at 1308.

224. Id. at 1311 tbl. 3 .

225. Id. at 1314 .

226. Id. at 1311 tbl. 3 .

227. Id at 1314 .

228. See generally REPRODUCTION AND RESPONSIBILITY, supra note 61, at 153 (discussing the costs of reproduction).

229. Ericson \& Kallen, supra note 186, at 504.

230. Id. at 505 tbl. 1 .

231. Id.

232. Id. 


\section{B. Rare Disorders}

This Part now considers two rare disorders. The first, BeckwithWiedemann syndrome (BWS), has multiple symptoms, including enlarged tongue and organs, abdominal wall defects, low blood sugar, lethargy, poor feeding, seizures, and predisposition to certain cancers. ${ }^{233}$ It results when genes on the maternal copy of chromosome 11 malfunction due to chromosomal abnormalities, gene mutations, or defects in the chemical imprints that regulate gene expression. ${ }^{234}$

BWS is rare, occurring in one out of 13,700 children. $^{235}$ Recent studies indicate children of ART have a six- to nine-fold greater risk of BWS compared with the general population. ${ }^{236}$ However, the absolute risk is still extremely low.

The second rare disorder, Angelman syndrome, ${ }^{237}$ also has multiple symptoms, including microcephalus, severe mental retardation, jerky movements, inability to speak, and inappropriate laughing. ${ }^{238}$ It results when the maternal copy of the UBE3A gene on chromosome 15 does not function, most often because of a chromosomal abnormality or gene mutation, but occasionally due to an imprinting defect. ${ }^{239}$

Angelman syndrome occurs in one out of 16,000 children. $^{240}$ In 2002 , German researchers raised eyebrows with a report that two ICSI children had Angelman syndrome because of an imprinting defect. ${ }^{241}$ A report of a third ICSI child who was similarly affected followed. ${ }^{242}$ Imprinting defects occur in

233. REPRODUCTION AND RESPONSIBILITY, supra note 61, at 39.

234. David J. Amor \& Janc Halliday, A Review of Known Imprinting Syndromes and Their Association with Assisted Reproduction Technologies, 23 HUM. REPROD. 2826, 2827 (2008). More specifically, there are two imprinting control regions on chromosome 11 , known as $\mathrm{ICI}$ and IC2. ICI is associated with a differentially methylated region (DMR). The patemal copy is methylated (imprinted) and regulates expression of the HI9 and IGF2 genes. IC2 is associated with a DMR known as KvDMRI. The matemal copy of KvDMRI is imprinted and rcgulates expression of the KCNQI and CDKNIC genes. Eamonn R. Maher, Imprinting and Assisted Reproductive Technology, 14 HUM. MOLECULAR GENETICS R133, RI36 fig.2 (2005).Two types of imprinting defects can causc BWS. In the first, the ICI DMR is imprinted in both patcmal and matemal copies. As a result, H 19 is silenced and IGF2 expresses itself from both patemal and maternal copies. Id. This accounts for $2-7 \%$ of BWS cases. Amor \& Halliday, supra at 2827 . In the second type, the maternal copy of KvDMRI loses imprinting, causing the matemal copy of CDKN1C to lose expression. Maher, supra at R136 fig.2. This accounts for around 40-50\% of all BWS cases. Id. at R135.

235. Amor \& Halliday, supra notc 234, at 2827.

236. See, e.g., Michacl R. DcBaun ct al., Association of In Vitro Fertilization with Beckwith-Wiedemann Syndrome and Epigenetic Alterations of LITI and HI9, 72 AM. J. HUM. GENETICS 156, 158 (2003) (cstimating at least a sixfold increase in BWS in children bom after ART as comparcd to the general population). See also Jane Halliday et al., Beckwith-Wiedemann Syndrome and IVF: A Case-Control Study, 75 AM. J. HuM. GENETICS 526, 527 (2004) (reporting the risk of BWS in IVF children as nine times greater than in the general population).

237. REPRODUCTION AND RESPONSIBILITY, supra note 61 , at 38-39.

238. Id. M. Ludwig et al., Increased Prevalence of Imprinting Defects in Patients with Angelman Syndrome Born to Subfertile Couples, 42 J. MED. GENETICs 289, 289 (2005).

239. Id.

240. Amor \& Halliday, supra note 234, at 2827.

241. Gerald F. Cox ct al., Intracytoplasmic Sperm Injection May Increase the Risk of Imprinting Defects, 71 AM. J. Hum. GeneTICS 162, 162 (2002). The matemal copy of SNRPN on chromosome 15, which should have been methylated, showed a loss of methylation. Id. at 163. SNRPN is an imprinting control center which regulates expression of the nearby UBE3A gene. Maher, supra note 234, at RI34 fig. 1 and accompanying caption.

242. K.H. Orstavik ct al., Another Case of Imprinting Defect in a Girl with Angelman Syndrome Who 
only $3-4 \%$ of Angelman syndrome patients. ${ }^{243}$ To some, it seemed improbable that such a rare syndrome with such a rare cause should manifest itself in three ICSI offspring as a matter of chance. ${ }^{244}$

At first, scientists feared that BWS and Angelman syndrome were linked to ICSI. ${ }^{245}$ Later, when it was discovered that only ten out of twenty-three ART-related BWS cases involved ICSI, scientists shifted their attention to the possibility that some other element of the IVF process was responsible for the increased risk. $^{246}$

Speculation has centered on the possibility that the materials and processes used to grow embryos in the lab are causing imprinting defects (and perhaps other as yet undetected errors in gene expression). ${ }^{247}$ In support of this theory, researchers argue that imprinting defects are seldom the cause of BWS and Angelman syndrome, except in children of ART. ${ }^{248}$ They also point to animal studies. Some cattle and sheep conceived through IVF and cloning have large offspring syndrome ${ }^{249}$ due to imprinting defects. ${ }^{250}$ IVF and embryo culture also have been observed to cause imprinting defects in mouse embryos. In one study, mouse embryos had the same type of imprinting defect linked to BWS in children conceived through ART. ${ }^{251}$

However, analogies to animal studies must be drawn with caution. Large offspring syndrome does not occur in children conceived through ART. ${ }^{252}$

Was Conceived by Intracytoplasmic Sperm Injection, 72 AM. J. HUM. GENETICS 218 (2003) (citing a loss of methylation on the maternal copy of the SNRPN gene on chromosome 15).

243. Ludwig, supra notc 238, at 289.

244. As one article explained, threc children with the imprinting disorder type of Angelman syndrome would be predicted out of 900,000 births. However, at the time of these studies, the estimated number of all ART births worldwide was only $1,000,000$. Thus, unless researchers had located all children bom with the imprinting disorder type of Angclman syndrome following ART (which secmed unlikely), rates of the disorder must be higher among ART offspring. Maher, supra note 234, at R134.

245. See, e.g., Cox ct al., supra note 241 at 162 (reporting 2 ICSI children with Angelman syndrome); DeBaun et al., supra note 236, at 158 (reporting that five out of seven BWS children studied had been conceived through ICSI).

246. See, e.g. Maher, supra notc 234, at R135 ("[I]t appears that ICSI per se is not the major determinant of the observed association between ART and imprinting disorders.").

247. See Kolata, supra note 179 at D6 (noting possible complications concerning the culture medium which might adversely affect embryo growth and devclopment).

248. See Maher, supra note 234, at R134-35 (stating that in a review of molecular data, twenty-three out of twenty-four ART babies with BWS showed imprinting loss at a specific sitc (KvDMRI) on the matemal copy of chromosome II; only $40-50 \%$ of spontancously conceived babies with BWS have the same defect); see also Cox ct al., supra note 241 at 162 (reporting on two ICSI babics that had been found to have a rare form of Angelman syndrome involving loss of imprinting on the maternal copy of chromosome 15); see also Orstaviket al., supra note 242 at 218-19 (describing, similarly, how one ICSI baby found also to have a rare form of Angelman syndrome).

249. See national academies, Scientific and Medical aspects of human Reproductive CLONING 41-42 (2002) (describing large offspring syndrome, which involves oversized of fspring, abnormal placentas, fluid accumulation and cardiovascular abnormalitics).

250. See Amor \& Halliday, supra note 234, at 2831 (describing cvidence of imprinting syndromes resulting from epimutations that have caused large offspring syndrome in shecp).

251. See id. at 2831-32 (citing R.M. Rivera ct al., Manipulations of Mouse Embryos Prior to Implantation Result in Aberrant Expression of Imprinted Genes on Day 9.5 of Development, 17 HuM. MOLECULAR GeNETICS 2008 at I).

252. MACINTOSH, supra note 43, at 52-53. Though nothing comparable to large offspring syndrome has been observed, one small study from New Zealand did find that IVF children were slightly taller on average than naturally conceived controls and had increased scrum levels of growth factors IGF-I and IGF-II. Harrict L. Miles et al., In Vitro Fertilization Improves Childhood Growth and Metabolism, 92 J. CLINICAL ENDOCRINOLOGY \& MET ABOLISM 344 1, 3443-45 (2007). The researchers speculated but did not show that the 
Rather, as we shall see, such children face an increased risk of low birth weight. $^{253}$

Moreover, there is another possible explanation. These rare disorders might result when severely infertile men and women conceive with sperm and eggs that carry or are susceptible to imprinting errors. ${ }^{254}$

Some research supports this interpretation. In 2007, Dutch researchers examined 220 Dutch children born with BWS, Angelman syndrome, or PraderWilli $^{255}$ syndrome. $^{256}$ They found that the children were three times more likely to be bom after ART than were children in the Dutch population. ${ }^{257}$ In other words, children of ART were overrepresented among the 220 children with disorders. However, the researchers also found that the families of these 220 children were three times more likely than families in the general Dutch population to have suffered from fertility problems of any kind. ${ }^{258}$ Since the relative risks were the same, the researchers concluded that the increased fertility problems of the parents fully explained the increased incidence of rare disorders after ART. ${ }^{259}$

German researchers also have found a link to infertility. The research team studied sixteen children with Angelman syndrome born to infertile couples. ${ }^{260}$ Elevated rates of the rare imprinting-defect form of the syndrome were found not only in children of couples who had undergone fertility treatment, but also in children of couples who had become pregnant without treatment but after more than two years of trying. ${ }^{261}$ The researchers suggested the parents might have a genetic predisposition to producing gametes and embryos that were epigenetically unstable. That would account for both their infertility (since most embryos would be too defective to survive) and

differences could be due to epigenetic alteration of imprinted genes. Id. at 3444 . Alternatively, larger and healthicr babies could result when doctors sclect the best quality cmbryos for implantation. $I d$.

253. See Maher, supra note 234, at RI36 (mentioning ART is associated with an increased frequency of low-birth weight in babies); see also infra tcxt accompanying notes $264-69$ (discussing low birth weight in children of ART).

254. See supra text accompanying notes 205-209 (discussing possible complications concerning sperm and eggs of severely infertile men and women).

255. See Amor \&Halliday, supra notc 234, at 2829 (noting that Prader-Willi syndrome occurs in around 1 out of 17,500 children, with symptoms including obesity, cognitive impairment, hypogonadism, and distinctive facial features; morcover, epigenetic mutations arc to blame in less than I\% of cases, and there have bcen no reports of ART offspring who have this syndrome on account of epimutations).

256. See Mariannc E. Doombos ct al., Infertility, Assisted Reproduction Technologies and Imprinting Disturbances: A Dutch Study, 22 HUM. REPROD. 2476, 2478 (2007) (detailing the results of a study testing fertility problems in connection with imprinting disorders).

257. See id. at 2477 (defining ART broadly to include not only IVF and ICSI but also intrauterine inscmination and the use of fertility drugs to stimulate ovulation). For Prader-Willi syndrome, the Dutch researchers found a significant association with fertility problems but not ART. Id. at 2478 .

258. Id . at 2478 . The study defined "fertility problems" as an inability to conceive within 12 months of unprotected intercourse and/or the usc of ART. "Fertility problems of any kind" referred to familics that had expcricnced such fertility problems in conceiving the child bom with the imprinting disorder, a normal sibling, or both. Id. at 2477 .

259. Id. at 2478 (ruling out the alternativc possibility of a "causal relationship between ART and imprinted discases").

260. See Ludwig et al., supra note 238 , at 289 (defining infertility as having received treatment for infertility, or taking more than two years to achieve a pregnancy).

261. See id. at 290 tbl. I (showing infertility-defect in both children of couples who had gone through fertility trcatment and children of couples who became pregnant without fertility treatment). 
increased risk of having a child with imprinting defects. ${ }^{262}$ For such parents, fertility drugs might further increase risk by stimulating the production of flawed eggs. ${ }^{263}$

\section{Perinatal Outcomes}

The final claim leveled against ART is that it produces children who have poor outcomes during the perinatal period immediately before and after birth.

As discussed above, CDC researchers caused a stir in 2002 when they declared the children of ART at increased risk for preterm delivery and low birth weight. ${ }^{264}$ In 2004, the CDC researchers published a follow-up study of singletons conceived through ART in 1996 through 2000. Compared with the general population, these babies had 1.41 times the risk of delivery before term (thirty-seven weeks), 1.62 times the risk of low birth weight (2500 grams or less), and 1.79 times the risk of very low birth weight (under 1500 grams). ${ }^{265}$

Taking the low birth weight data and breaking it out, the CDC researchers found that singletons borm prematurely had 1.74 times the risk of low birth weight. $^{266}$ However, singletons born at term had only 1.39 times the risk of low birth weight ${ }^{267}-\mathrm{a}$ big drop from the headline-grabbing 2.6 increase reported back in $2002 .{ }^{268}$ The researchers could not explain the improvement, but speculated that increased use of ultrasound-guided embryo transfer might have improved the position of the placenta (the vehicle for fetal nutrition). ${ }^{269}$

The CDC researchers also found that ICSI did not increase these risks. ${ }^{270}$ To the contrary: ICSI singletons had risk ratios that were slightly lower for each measured outcome, except for low birth weight at term. ${ }^{271}$

Turming to multiples, the 2002 CDC study found that ART twins borm at term did not show an increased risk of low birth weight compared with twins

262. See id. ("Based on these findings, we propose that there is some genetic predisposition, possibly of a heterogencous nature, to epigenetic instability of gametes or carly embryonic cells.").

263. See id. (" $[\mathrm{H}]$ ormonal stimulation, which is also used for ICSI, may lead to the maturation of "poor quality' ooctyes that would not have been ovulated without treatment, or that a too rapid maturation provoked by the hornonal stimulation procedure disturbs the process of DNA methylation in the oocyte.").

264. See supra text accompanying notes $80-83$.

265. Laura A. Schicve ct al., Perinatal Outcome among Singleton Infants Conceived Through Assisted Reproductive Technology in the United States, 103 OBSTETRICS \& GYNECOLOGY 1144, 1144 (2004) [hercinafter Schicve III].

266. Id.

267. Id.

268. Schicve II, supra note 80.

269. Schicve III, supra note 265, at I15I. Similarly, a University of California at San Francisco team meta-analyzed data from fiftecn studies and found IVF singletons had two times the risk of preterm delivery, 1.8 times the risk of low birth weight, 2.7 times the risk of very low birth weight, 1.6 times the risk of being born small for their gestational age (birth weight less than tenth percentile), and 2.2 times the risk of being stillborn or dying within seven days of birth. See Rebecca A. Jackson ct al., Perinatal Outcomes in Singletons Following In Vitro Fertilization: A Meta-Analysis, 103 OBSTETRICS \& GYNECOLOGY 551, 552, 554 (2004) But see Shevell ct al., supra note 172, at 1043 (finding no association between ART and low birth weight).

270. Schicve III, supra note 265 .

271. Schicve III, supra note 265, at 1148,1150 tbl. 4; cf. Maryse Bonduclle et al., Neonatal data on a cohort of 2889 infants born after ICSI (199I-1999) and of 2995 infants born after IVF (1983-1999), 17 HUM. REPROD. 671, 682 (2002) (finding similar birth weights in ICSI and IVF singletons and concluding that ICSI docs not add to risk of low birth weight associated with IVF). 
in the general population, ${ }^{272}$ and most subsequent studies have produced similar results. ${ }^{273}$ But, these favorable results might be misleading given the higher percentage of monozygotic twins (and risk) among spontaneously conceived babies. $^{274}$ To correct for this, a recent Australian study used spontaneously conceived boy-girl twins (presumed to be dizygotic) as controls. $^{275}$ The researchers found ART twins had an increased risk of poor outcomes, including preterm birth, low birth weight, and perinatal death. ${ }^{276}$

The increased rates of low birth weight and preterm birth in children of ART are worrisome. Children who enter the world with low birth weight are at increased risk for hypertension, cardiac disease, stroke, and perhaps osteoporosis in midlife. ${ }^{273}$ Those bom very preterm face an increased risk of medical disabilities, such as cerebral palsy and mental retardation. ${ }^{278}$ So, the question arises: what is the cause of these poor outcomes and can anything be done about it?

Again, some researchers blame ART. For example, the 2004 CDC report speculated that drugs used to stimulate ovulation and prepare the uterus for implantation might affect the uterine lining, cervix, and placenta, or impair synchronization of the embryo with the uterine lining. ${ }^{279}$ However, such speculations remain unproven.

Cryopreservation is another common feature of ART. But, a recent review of the medical literature concluded children bom from frozen embryos were no more likely to be borm preterm or at low birth weight. ${ }^{280}$

Multiple-embryo transfer is yet another possible cause of poor perinatal outcomes. We know from ultrasound exams that some embryos implant, perhaps even develop a heartbeat, and then mysteriously vanish. Among ART singletons, one out of ten is the sole survivor of a vanishing twin pregnancy. ${ }^{281}$

272. Schicve II, supra notc 80 , at 736 .

273. For example, Canadian researchers reviewed the literature and deduced that IVF twins were about 1.5 times more likely to be born preterm than spontancously conceived twins, but no more likely to dic or have low birth wcight. McDonald ct al., supra notc 182, at 141 .

274. See supra tcxt accompanying notcs 183-85; see also McDonald et al., supra notc 182, at 149 (stating IVF twins had worsc perinatal outcomes in other studics that matched for zygosity or gender).

275. Hansen Il, supra note 186, at 2321.

276. Id. at 2323 tbl. I, 2322-33.

277. Winston \& Hardy, supra notc 187 , at $\mathrm{S} 18$.

278. See Dag Mostcr ct al., Long-Term Medical and Social Consequences of Preterm Birth, 359 NEW ENG. J. MED.262, 266 (2008). This extensive study of more than 900,000 Norwegian births found that as gestational agc decreased, disabilitics increased. See id. at 268-72. For cxample, less than I\% of infants born at term had cercbral palsy. Howcver, $6 \%$ of infants born from twenty-cight to thirty wecks had cercbral palsy, and the rate increased to $9 \%$ for infants born from twenty-threc to twenty-seven wecks. See id. at 268 tbl. 2 (showing the ratc of cercbral palsy across different gestational pcriods).

279. See Schicve III, supra notc 265, at 1151; see also K. Kapitcijn ct al., Does Subfertility Explain the Risk of Poor Perinatal Outcome after IVF and Ovarian Hyperstimulation? 21 HUM. REPROD. 3228, 3231 tbl. IV (2006) (reporting that singletons bom to women treated with ovulation inducing drugs had double the risk of birth bcfore thirty-two wecks and triple the risk of very low birth weight compared with of fspring of infertile women who conecived spontancously).

280. Wennerholm et al., supra note 198, at 2168. Indecd, some of the reviewed studies showed children born from frozen embryos as having lower rates of preterm birth and low birth weight. Id. The reasons are unknown; cmbryos capable of surviving the freczing and thawing process might be of better quality. Id. at 2169. Similarly, children conccived with frozen donor sperm do not face an increased risk of preterm birth, low birth wcight, or perinatal mortality. Lansac \& Roycre, supra notc 198, at 34.

281. Anja Pinborg ct al., Consequences of Vanishing Twins in IVF/ICSI Pregnancies, 20 HUM. REPROD. $2821,2826(2005)$. 
According to a Danish study, when compared with ART babies born after single gestations, survivors of vanishing twins face 1.7 times the risk of low birth weight, 2.1 times the risk of very low birth weight, and 1.3 times the risk of preterm birth. ${ }^{282}$ The risk of cerebral palsy doubles, ${ }^{283}$ and the risk of child death triples. ${ }^{284}$ Most of the increased risk comes from losses that happen after eight weeks gestation. ${ }^{285}$

However, vanishing twins appear not to be the only reason for poor perinatal outcomes; CDC researchers separately analyzed cases in which only one fetal heart was detected and found that the risk of low birth weight decreased slightly but did not disappear. ${ }^{286}$

A fourth possibility has little to do with ART and everything to do with parents, particularly mothers. Though the root causes remain unclear, a number of studies suggest that infertile women may be more likely to give birth early and to have children with low birth weight.

For example, the $2004 \mathrm{CDC}$ report ran various analyses of the available data. $^{287}$ One analysis looked at a subset of singletons born to couples with male factor as the only infertility diagnosis (in other words, the mothers were healthy and fertile). This group had the lowest risks of preterm delivery and preterm low birth weight. The researchers conceded that maternal infertility might account for poor perinatal outcomes, at least in part. ${ }^{288}$

Norwegian researchers have reached a stronger conclusion. Working from a database of more than one million births over a span of twenty-two years, Liv Bente Romundstad and her research team found data for 2204 women who had conceived some of their children spontaneously and others through IVF. ${ }^{289}$ The singletons conceived through IVF had an increased risk of low birth weight, short gestation, small size for gestational age, premature delivery, and perinatal death when compared with babies from the general population. $^{290}$ But, these differences disappeared or were minimal when the researchers compared the IVF singletons with their spontaneously conceived siblings. ${ }^{291}$ In other words, babies born of the same mother were no worse off

282. Id. at 2825 tbl. IV. The odds ratios cited in this paragraph refer to survivors whose twins vanished prior to twenty-two wecks of gestation. Survivors of stillborn twins were excluded.

283. Id. at 2825. Thus, vanishing twins may help to account for the incrcased risk of cerebral palsy that some studics have noted among IVF singletons. Alastair G. Sutcliffe \& Michacl Ludwig, Outcome of Assisted Reproduction, 370 LANCET 351, 355 (2007).

284. Pinborg ct al., supra note 281 , at 2825 (2005).

285. Id. at 2826.

286. Schicve II, supra note 80 , at 736 tbl. 4; Schicve III, supra note 265 , at 1150 tbl. 4. Some have eriticized the CDC rescarchers on the ground that they did not account for ancmbryonic gestations, which could have a negative impact cven if no fetal heart developed. See Kovalevsky ct al., supra note 84, at 1271 (contending that not controlling for anembryonic gestations could have a negative impact regardless of fetal heart development). It is biologically plausible that such gestations could have some impact. However, since vanishing twins have the most serious consequences when they disappear after eight wecks, Pinborg et al., supra note 281 , at 2826 , carly gestations that never develop a fetal heart probably do not entirely account for poor perinatal outcomes.

287. Schicve III, supra notc 265 at 1144.

288. Id., at 1148,1151 .

289. Liv Bcnte Romundstadt et al., Effects of Technology or Maternal Factors on Perinatal Outcome after Assisted Fertilisation: A Population-Based Cohort Study, 372 LANCET 737, 738 (2008).

290. Id. at 737.

291. For deliveries from the same mother, the researchers adjusted for maternal age, parity, offspring sex, 
when conceived through IVF. From this, the researchers concluded that infertility could be the cause of poor perinatal outcomes. ${ }^{292}$

A study of singletons conceived through ovulation induction and IUI supports this conclusion. Babies conceived with donor sperm had similar perinatal outcomes to spontaneously conceived controls. ${ }^{293}$ Since donor sperm is used when the male partner is infertile and the female partner is fertile, this result implied that babies were fine when the mother was fine. But, babies conceived with a partner's sperm faced an increased risk of preterm delivery and had nearly five times the risk of low birth weight. These results implied that infertility in women and their partners caused poor perinatal outcomes. ${ }^{294}$

Finally, other researchers have studied infertile women who became pregnant without any fertility treatment. The findings were striking: the longer it took women to achieve pregnancy (and thus the more intractable their infertility), the greater their risk of producing children with preterm birth, low birth weight, small size for gestational age, and perinatal death. ${ }^{295}$

\section{EUGENICS IN THE TWENTY-FIRST CENTURY}

Scientific studies that provide us with more knowledge about ART are good. Such knowledge may allow fertility doctors to improve treatment protocols and lab conditions, thereby safeguarding the health of patients and their children. Such knowledge may also enable infertile men and women to give consent that is truly informed. ${ }^{296}$

However, the studies may also be used for less benign purposes. Lawmakers and regulators could assert them as grounds to restrict access to IVF, ICSI, or other ART. ${ }^{297}$ What forms might such legislation or regulation take?

time between pregnancies, and year of delivery. Id. at 739. They also considered order of mode of conception (i.c., whether the IVF or spontancously conceived child was born first) and found it made little or no difference to most of their findings. Id. at 739-40. The exception was perinatal mortality, which was four times morc likely when the spontancous conception occurred before the IVF pregnancy. Id. at 740-41. The researchers speculated that a perinatal death could damage subsequent fertility or indicate inherently impaired fertility. Id. at 742 .

292. See id. at 742 ("a perinatal death could indicate an inherent tendency for adverse pregnancy outcomes or could have a strong effect on subsequent fertility").

293. See Marco Gaudoin, Ovulation Induction/Intrauterine Insemination in Infertile Couples Is Associated with Low-Birth-Weight Infants, 188 AM. J. OBSTETRICS \& GYNECOLOGY 611, 615 (2003) ("This finding agrees with a larger report showing that the perinatal outcome of infants conceived with donor semen is no different from that of infants conceived naturally.").

294. See id. at 615-16 (stating that factors related to subfertility could cause low-birth-weight infants).

295. See Sutcliffe \& Ludwig, supra note 283, at 353 (summarizing results of several studics, including Elizabeth Draper et al., Assessment of Separate Contributions to Perinatal Mortality of Infertility History and Treatment: A Case-control Analysis, 353 LANCET 1746 (1999) (of fspring of untreated infertile women threc times more likely to suffer perinatal death))

296. See, e.g., Jackson ct al., supra note 269, at 561; John Robertson, Procreative Liberty and Harm to Offspring in Assisted Reproduction, 30 AM. J.L. \& MED. 7, 25 (2004).

297. See Robertson, supra note 297, at 24-25 (anticipating legal restrictions on ART based on studies showing an increased risk of birth defects, rare disorders such as Beckwith-Wicdemann syndrome, and low birth weight). 


\section{A. Legislative Bans and Regulatory Impediments}

Congress is unlikely to ban ART, for two reasons. First, though any one state may have only a small fertility industry, on a national level the industry is substantial. Faced with a threat to their businesses and jobs, thousands of doctors, nurses, lab technicians, and other professionals would lobby hard against a federal ban.

Second, technologies involving human life bring abortion politics into play and create legislative gridlock. For example, Congress has been unable to ban reproductive cloning because its members cannot agree on whether to ban research cloning (which destroys embryos). ${ }^{298}$

A proposal to ban ART could lead to a similar stalemate. Conservatives would probably support such legislation; the Roman Catholic Church and other pro-life forces have long objected to IVF on the ground that some embryos fail to implant or are discarded. ${ }^{299}$ Liberals would oppose the legislation out of concern that protecting IVF embryos could undermine abortion rights.

However, state legislatures are a different matter. Just as conservative states have banned both reproductive and research cloning, ${ }^{300}$ conservative states might ban ART. Safety concerns could provide conservative legislators with a convenient excuse for attacking technologies that they already oppose on religious or ideological grounds. And even in states where conservatives ordinarily would not command enough votes to ban a controversial technology, safety concerns could sway enough moderates to tip the legislative balance in favor of a ban.

State legislatures are not the only threat to ART. Federal regulatory agencies may also take action. For example, the FDA has already halted cloning, nuclear transfer, and ooplasm transfer. In the case of ooplasm transfer, the agency cited as justification the conception of two Turner syndrome fetuses - a result that could have been caused by advanced maternal age rather than the technology involved. ${ }^{301}$ Given the right witch's brew of experimental results, media hype, and demand for safety regulation, the FDA could decide to expand its already questionable jurisdiction to encompass ART, particularly methods such as ICSI that achieve the union of sperm and egg by "unnatural" means. If recent experience is any guide, the FDA would then refuse to grant permission to use any technology brought within its jurisdiction.

Critics might even persuade Congress to create a new agency charged with oversight of ART. ${ }^{302}$ The agency would conduct research and review the

298. See MACINTOSH, supra note 43, at 76-79 (stating that there were efforts to ban reproductive cloning only, but the bill was never put to a vote in the Senate because many lawmakers were against the destruction of human cmbryos).

299. The Roman Catholic Church also holds that IVF is immoral becausc procreation should result from sexual intercourse between a marricd man and woman. CONGREGATION FOR THE DOCTRINE OF THE FAITH, instruction Dignitas Personae on Certain Bioethical Questions, fif 14-16 (2008). The Church condemns ICSI on the ground that it allows technology to dominate the origin and destiny of the human person. See id. at $\| 17$.

300. MACINTOSH, supra notc 43 , at $85-86$.

301. See supra text accompanying note 130 .

302. See supra text accompanying notes 90-91. 
results of external scientific studies. If research indicated that children conceived through ART had an increased risk of health problems, the agency might blame the technology rather than heredity and restrict access.

The foregoing comments assume that regulators will act out of genuine concern for the safety of children. But, it bears mentioning that regulators can also exploit safety concerns to achieve political goals.

To illustrate, consider the FDA's decision to assert jurisdiction over reproductive cloning. Dr. Richard Seed's declaration in early 1998 that he planned to clone a baby fanned the flames of public hysteria and encouraged Congressional conservatives to demand a federal ban on all cloning, including for research. ${ }^{303}$ At that time, however, President Bill Clinton was in office, and the appointed members of his National Bioethics Advisory Council had recommended the year before that Congress prohibit only the cloning of babies. ${ }^{304}$ By declaring that it had the authority to halt reproductive cloning on safety grounds, the FDA cleverly headed off a legislative ban and permitted research cloning to continue. ${ }^{305}$

A future President with pro-life views could do something similar. He or she could staff the FDA or a new regulatory body with conservative appointees who would be more than happy to assert the dangers of ART as a rationale for prohibiting methods of conceiving children that offend their values. ${ }^{306}$

\section{B. Brave New Eugenics}

At first glance, these possibilities may not seem troubling. Protecting children from birth defects and other health hazards is a worthy goal-so much so that many people would accept increased regulation despite the risk that politicians might twist the science around to achieve ideological ends.

However, before embracing safety-based restrictions on ART, we should consider historical parallels with eugenic sterilization laws of the twentieth century. The more parallels we find, the stronger the argument that we are stumbling towards a brave new eugenics, with the infertile and their children as the targets.

\section{Eugenic Sterilization in the Twentieth Century}

In 1865, Francis Galton claimed that humans inherited intellectual, psychological, and physical traits. ${ }^{307}$ From there he leaped to the bold

303. See Price, supra note 136, at 623-26 (noting that Republican-sponsored bills offered in response to Dr. Secd's declaration contained language broad enough to "ban any use of somatic cell nuclear transfer, including potentially useful stem cell rescarch").

304. See NBAC REPORT, supra note 93, at 109 ("Federal legislation should be enacted to prohibit anyone from attempting ... to create a child through somatic cell nuclear transfer cloning.").

305. See Price, supra note 136, at 625-28 (outlining the background of the FDA's decision to assert jurisdiction).

306. Cf. Carson Strong, Too Many Twins, Triplets, Quadruplets, and So On: A Call for New Priorities, 31 J.L. MED \& ETHICS 272, 279 (2003) ("There are a number of topics related to infertility treatment ... that are subject to political controversy. Although such topics might not initially be intended for regulation, politicians might sec an opportunity for political gain by attempting to regulate activitics associated with them.").

307. Daniel J. Kevles, In the Name of Eugenics 3-4 (Harvard University Press 1995) (1985). 
conclusion that human evolution should not be left to chance. ${ }^{308}$ Men and women with superior traits should be encouraged to reproduce, while those with inferior traits should be discouraged from having offspring. ${ }^{309}$ Galton later coined the term "eugenics" (from the Greek eugenes meaning "good in birth") to describe his plan for selective breeding. ${ }^{310}$

The emergence of genetics gave a boost to eugenics. In 1883, a German scientist named August Weismann provided evidence that sperm and eggs were unaffected by environment and transmitted from parents to offspring without change. ${ }^{31}$ And, around 1900, biologists rediscovered Gregor Mendel's theory that heritable elements contained in seeds controlled the traits of offspring. ${ }^{312}$

As the twentieth century dawned, the eugenics movement began to blossom. Researchers collected family genealogies and used the data to argue that feeblemindedness, ${ }^{313}$ insanity, epilepsy, alcoholism, criminality, and even poverty were heritable. $^{314}$ The American Eugenics Society and the Human Betterment Foundation sponsored lectures, research, and propaganda. ${ }^{315}$ Soon the movement claimed a wide range of supporters, including scientists, doctors, conservatives, socialists, feminists, and philanthropists. ${ }^{316}$

Meanwhile, vasectomy had been invented at the turn of the century, making sterilization safer and cheaper than it had been in the days when castration was the only alternative for men. ${ }^{317}$ Lawmakers quickly recognized the potential of the new technology; in 1907, Indiana enacted the first eugenic sterilization law. $^{318}$ By the mid-twenties, state laws mandated sterilization of the feebleminded, rapists, habitual criminals, epileptics, alcoholics, life prisoners, syphilitics, drug addicts, sexual perverts, and moral degenerates, among others. 319

308. Id.

309. Id.

310. Diane B. Paul, Controlling human Heredity, 1865 to the Present 3 (1995).

311. Id. at 41 .

312. See KEVLES, supra notc 307, at 41-44 (detailing how Mendel's 1865 thcory languished for decades until other biologists began to conduct experiments of their own confirming that Mendel was correct).

313. See id. at 46,78 (writing that cugenicists used the term "fecbleminded" to describc a broad range of mental disabilities and nonconf orming bchavior.).

314. Id. at $46,55-56$

315. Id. at 59-62; Philip R. Reilly, The Surgical Solution 76-81 (1991).

316. See Martin S. Pernick, The Black Stork: Eugenics and the Death of "Defective" Babies in AMERICAN MEDICINE AND MOTION PICTURES SinCE 1915, at 6-7 (1996) ("A substantial number of very prominent carly-twentieth-century Americans favored letting deformed infants die."); KEVLES, supra note 307, at 63-64 ("In the United States, the eugenics movement brought together conservatives like Davenport with progressives like Gifford Pinchot, Charles R. Van Hisc, Charles W. Eliot, and David Starr Jordan and radicals like Emma Goldman and Hermann J. Muller, a futurc Nobcl [L]aureate for his work in genctics .....); PAUL, supra note 310, at 17-21 (describing the cugenic movement's broad range of appcal to many people of different intercsts, backgrounds, and political affiliations).

317. REILLY, supra notc 315 , at 31 ; see also KEVLES, supra notc 307 , at 53 (noting that even after the vasectomy was invented, some castrations werc performed in an effort to reduce sex drive); Jeffrey F. Ghent, Annotation, Validity of Statutes Authorizing Asexualization or Sterilization of Criminals or Mental Defectives, 53 A.L.R. 3d 960, § 2[a], at 964 (1973) (noting in early cases the court construcd the statute as permitting castration as well as vasectomy).

318. See Ghent, supra note 317 , at 963 (noting sterilization of confirmed criminals, idiots, imbeciles, and rapists in state institutions was mandatory upon a recommendation by a board of experts).

319. See Jeffrcy M. Shaman, Persons Who Are Mentally Retarded: Their Right to Marry and Have Children, 12 FAM. L.Q. 61, 75 (1978-1979) (citing HARRY HAMILTON LAUGHLIN, EUGENICAL STERILIZATION 
Courts invalidated some laws for failure to provide procedural due process basics like notice, hearing, and representation. ${ }^{320}$ They threw out other laws for limiting sterilization to inmates of institutions in violation of equal protection. ${ }^{321}$ However, state lawmakers were not discouraged. They enacted new laws and modified old ones to correct such constitutional deficiencies. ${ }^{322}$

Virginia was one of the states that had a eugenic sterilization law. ${ }^{323}$ Pursuant to its law, a teenager named Carrie Buck was declared feebleminded and ordered to undergo sterilization: ${ }^{324}$ In Buck $v$. Bell, ${ }^{325}$ the United States Supreme Court upheld the sterilization order, reasoning that it did not violate Carrie's substantive due process ${ }^{326}$ or equal protection rights. ${ }^{327}$

The Buck decision gave the legal green light to eugenic sterilization. Twenty-four states had sterilization laws at the end of the nineteen-twenties, ${ }^{328}$ and by 1942 that number had climbed to thirty-two states. ${ }^{329}$ Sterilizations surged during the Great Depression of the nineteen-thirties, running from 2000 to 3000 cases in most years ${ }^{330}$ and shifting in focus from men to women. ${ }^{331}$

Fortunately for the nation, eugenic sterilization declined during the

18-50 (1925) available at http://dnapatents.georgetown.cdu/resources/EugcnicalSterilization InTheUS.pdf).

320. See Ghent, supra note 317, at 964 (noting invalid statutes are those with an inadequatc duc process standard for notice, hearing, opportunity to confront or cross-cxamine witnesses, or right of appeal).

321. See id. at 965 (stating statutes arc invalidated on duc process grounds when they create arbitrary classifications); KEVLES, supra note 307, at 109 (explaining that many state sterilization statutes "ran afoul of the courts" duc to the lack of basic procedural protection afforded the stcrilization candidates and duc to the statutes' focus on sterilizing those confined to state institutions); REILLY, supra note 315, at 50-55 (describing how numerous legal attacks on the sterilization statutes, based on due process and equal protection challenges, negated the legal victorics won by sterilization supporters).

322. See REILLY, supra note 315, at 84-85 (explaining that after the period of 1918 to 1922, in which legislative enactment of sterilization laws slowed down, proponents of eugenics drafted new laws "that purported to saf eguard the procedural rights" of the potential candidates).

323. See KEVLES, supra note 307, at 110 (noting that with the drafting assistance of cugenicists the Virginia legislature passed a stcrilization statutc in March 1924).

324. Buck v. Bell, 130 S.E. 516, 517 (Va. 1925). Carric had been sent to an institution for the fecbleminded after bearing a non-marital child. Id. Those who advocated her sterilization claimed that Carrie was the daughter of a fecbleminded woman, had the mind of a nine year-old child herself, and had given birth to an infant daughter who was mentally defective. $I d$. Professor Paul Lombardo paints a very different picture. According to his rescarch, Carric was a prolific reader and had a clear memory even in old age, belying the intelligence testing that labeled her as fecbleminded. Far from being an imbecile, her daughter was very bright, making the honor roll in grade school before dying young of an infectious disease. Paul A. Lombardo, Three Generations, No Imbeciles: New Light on Buck v. Bell,60N.Y.U. L. Rev. 30, 61 (1985).

325. 274 U.S. 200, 208 (1927)

326. Justice Oliver Wendell Holmes penned the decision. In rejecting Carric's substantive due process claim, he reasoned that sterilization laws were necessary to prevent the nation from being "swamped with incompetence." $I d$. at 207 . He followed this up with the infamous obscrvation that "[t]hrec generations of imbeciles are enough." Id.

327. Carric argued the law violated equal protection becausc it subjected only institutional inmates like her to sterilization. Justice Holmes rejected the argument, rcasoning that the Virginia law sought to bring all similarly situated persons within its scope as far and fast as possiblc. In a cruel twist, he added that allowing current inmates to be sterilized and released into the world would open space in the asylum for more inmates, thus increasing equality of treatment. Id. at 208.

328. KEVLES, supra note 307, at 111.

329. Ghent, supra note 317 , at 963.

330. REILLY, supra note 315 , at $97,101,129$.

331. Id. at 98 . Salpingectomy (a procedure similar to tubal ligation) was invented later than vasectomy. The pioneer was a German surgeon who sterilized eighty-nine women between 1910 and 1920. Id. at 34 . Apparently it took some time for other doctors to learn about the new procedure and develop the confidence and skill to use it. 
nineteen-forties and fifties, along with the eugenics movement. ${ }^{332}$ Scholars have noted several reasons for the decline, including horror at Nazi excesses, ${ }^{333}$ diversion of doctors into military service during World War II, ${ }^{334}$ and Roman Catholic opposition. ${ }^{335}$

Ironically, the U.S. Supreme Court that had done so much to encourage eugenic sterilization also played a role in bringing the gruesome practice to an end. The 1942 case of Skinner $v$. Oklahoma presented a constitutional challenge to an Oklahoma law mandating sterilization of criminals. ${ }^{336}$ Casting marriage and procreation as basic rights, the Court reasoned that the classifications made in a sterilization law had to be subjected to strict scrutiny. ${ }^{337}$ Finding no meaningful eugenic distinction between thieves and robbers, who were subject to the law, and embezzlers, who were not, the Court invalidated the law on equal protection grounds. ${ }^{338}$ Though the Court did not overrule Buck v. Bell, its holding signaled to legislators that the judiciary was no longer enthusiastic about eugenic sterilization.

With this background in mind, this Article now considers whether laws or regulations that ban or restrict ART on safety grounds are similar to eugenic sterilization laws. Four points will be discussed: whether the laws target the disabled; whether the laws seek to prevent transmission of health problems from one generation to the next; whether the laws interfere with reproduction; and whether the laws have common underlying goals.

\section{Infertile Men and Women Are Disabled}

Turning to the first point, the Americans with Disabilities Act of 1990

332. Id. at 128; see also James B. O’Hara \& T. Howland Sanks, Eugenic Sterilization, 45 GEO. L.J. 20, 35 (1956) (discussing the "steady decline" of eugenic sterilization during this time period). By 1955, the number of annual operations had dwindled to around 1000. Id. A few states continued the unwclcome surgeries into the ninetecn-sixtics and scventics. See REILLY, supra note 315, at 143, 149 (discussing instances of cugenic sterilizations during this period). Around 60,000 mentally ill or disabled Americans were sterilized from 1907 to $1960, i d$. at 2, with more than half the victims in Califomia. PAUL, supra note 310, at 83.In 1978, the Department of Health, Education and Welfare published regulations that prohibit federally-funded programs from sterilizing individuals without their signed consent and a thirty-day waiting period. 42 C.F.R. $\S \S 50.201,50.203,50.204,50.205$ (2008); REILLY, supra note 315, at 152. Under no circumstances may such programs sterilize persons who are mentally incompetent or institutionalized. See 42 C.F.R. $§ 50.206$ (2008) (banning stcrilization of mentally incompetent individuals).

333. See, e.g., KEVLES, supra notc 307, at 251. The Nazis borrowcd bclicfs and stratcgies from the American cugenics movement. See generally StEFAN KuHL, THE NAZI CONNECTION: Eugenics, AMERICAN RACISM, AND German National Socialism (1994) (describing how Amcrican scholars inspircd Nazi movement in Germany during the carly twenticth century). Acting pursuant to the Law for the Prevention of Genetically Discased Progeny, the Nazis sterilized at least 300,000 to 400,000 persons with mental or physical disabilitics. PAUL, supra note 310 , at 89 . They also cxccuted mental patients. REILLY, supra note 315 , at 110.

334. REILLY, supra notc 315, at 128.

335. In 1930, Pope Pius XI relcased Casti Connubi: ON Christian Marriage. This encyclical declared it beyond the proper authority of the state to block marriage and sterilize men and women in order to prevent hereditary transmission of defects to offspring. The encyclical also condemned voluntary sterilization and birth control as a means of reducing family sizc. Id. at 119-20. Responding to this guidance, clcrics and lay Catholics lobbicd against and defeated many sterilization bills during the ninctecn-fortics. Id. at 120; O'Hara \& Sanks, supra notc 332, at 38.

336. Skinner v. Oklahoma, 316 U.S. 535 (1942).

337. Id. at 541 .

338. See id. at 541-42 (finding discrimination occurred when those who committed larceny werc sterilized, but not those who were guilty of embezzlement). 
$(\mathrm{ADA})^{339}$ prohibits discrimination against disabled persons, not only in employment and places of public accommodation, but also by public entities such as state and local governments. ${ }^{340}$ This federal law reflects national policy; accordingly, this Article will use it to determine whether laws that ban or restrict ART are similar to eugenic sterilization laws because both target the disabled.

Congress enacted the ADA Amendments Act of 2008 to clarify its intent to provide broad protection against discrimination for disabled persons. ${ }^{341}$ As amended, the ADA defines the "disability" of an individual to include "a physical or mental impairment that substantially limits one or more major life activities of such individual." 342

Eugenic sterilization laws targeted not only criminals and others who transgressed social norms, but also persons with epilepsy, feeblemindedness, sexually transmitted disease (syphilis), and alcoholism. ${ }^{343}$ Today, regulations that implement the ADA define "physical or mental impairment" to include epilepsy, mental retardation, human immunodeficiency virus (HIV) disease, drug addiction, and alcoholism. ${ }^{344}$ Since such diseases or conditions can often substantially limit a major life activity, it seems likely that many victims of sterilization laws would be considered disabled today under the ADA.

Many infertile men and women also should be considered disabled under the ADA, for three reasons. First, inability to conceive a child through unprotected sexual intercourse will of ten be due to a "physical impairment." 345 Second, the Supreme Court has recognized that reproduction is "substantially limited" for HIV-infected individuals because it would expose their sex partners and offspring to the risk of infection. ${ }^{346}$ Most infertile men and women will have an even stronger case because their physical impairments will make reproduction impossible without medical assistance. ${ }^{347}$ Finally, the

339. Amcricans with Disabilities Act of 1990, 42 U.S.C. $\S \S 12101-12213$ (2006), amended by ADA Amendments Act of 2008, Pub. L. No. 110-325, 122 Stat. 3553 (2008).

340. See 42 U.S.C. $\S \S 12132,12182$ (2006) (prohibiting discrimination on the basis of disability by public entitics and prohibiting discrimination on the basis of disability in places of public accommodation); see also ADA Amendments Act of 2008, Pub. L. No. 110-325, sec. 5, § 12112, 122 Stat. 3553, 3557 (prohibiting discrimination on the basis of disability in employment); HENRY H. PERRITT, JR., AMERICANS WITH DiSABILITIES ACT HANDBOOK $\S \S 4.03[\mathrm{~A}], 6.03[\mathrm{~A}]$ (4th cd. 2003) (prohibiting discrimination on the basis of disability in various settings).

341. See ADA Amendments Act of 2008, Pub. L. No. 110-325, sec. 2(b)(1), 122 Stat. 3553, 3554 (discussing the purposes of the Act).

342. Id. at sec. $4, \S 12102(1)(\mathrm{A}), 122$ Stat. at 3555.

343. See supra text accompanying notc 319 (listing the targets of cugenic stcrilization laws).

344. See 28 C.F.R. § 35.104(1)(ii) (2009) (defining "physical or mental impairment").

345. See 29 C.F.R. § 1630.2(h)(1) (2009) (defining a physical impairment as any physiological disorder or condition that affects the reproductive system); see also Pacourck v. Inland Stcel Company, 916 F. Supp. 797, 801 (N.D. 11l. 1996) (recognizing the inability to reproduce as a physical impairment even when the precise causc of the infertility is unknown). Whether infertility resulting from advanced maternal age qualifics as a disability is an open question. See Saks v. Franklin Covey Co., 117 F. Supp. 2d 318, 326 (S.D.N.Y. 2000), aff d in part, 316 F.3d 337 (2d Cir. 2003) (indicating that at least one court has suggested in dictum that a post-menopausal woman who could not conceive would not be considered disabled).

346. See Bragdon v. Abbott, 524 U.S. 624, 639 (1998) (holding reproduction is "substantially limited" for HIV infected individuals).

347. See Peter K. Rydcl, Redefining the Right to Reproduce: Asserting Infertility as a Disability under the Americans with Disabilities Act, 63 ALB. L. REV. 593, 632 (1999) (indicating that infertility precludes reproduction). 
ADA as amended in 2008 expressly recognizes reproductive function as a "major life activity.",348

The classification of infertile men and women as disabled follows even in cases where ART may permit them to have children. Through its 2008 amendments, Congress has directed courts to disregard the ameliorative effects of mitigating measures such as medication or assistive technology when determining whether a physical impairment substantially limits a major life activity. ${ }^{349}$

\section{Transmission of Health Problems}

Moving on to the second point, the question is whether laws that ban or restrict ART attempt to prevent transmission of health problems from parent to child, as eugenic sterilization laws once did.

At first glance, the answer seems to be no. Critics have complained that parents and doctors are inflicting unsafe technologies on children who cannot consent to the dangerous circumstances under which they are conceived. For the most part, the debate has not explicitly focused on transmission of traits. ${ }^{350}$

However, chromosomal, genetic, and epigenetic abnormalities contribute to infertility, ${ }^{351}$ and infertility is associated with an increased risk of conceiving children who suffer from birth defects, imprinting errors, and poor perinatal outcomes. $^{352}$ IVF and ICSI enable a subset of infertile men and women to overcome these natural barriers and conceive children who are at risk due to underlying parental characteristics. ${ }^{353}$ Thus, upon closer examination, the drive to ban "unsafe" technology turns out to be something else: a drive to stop a group of disabled persons from transmitting health problems to their children.

This conclusion may come as a surprise to well-intentioned academics and policymakers who want only to protect unborn children against what they perceive as an overreaching fertility industry. However, this link between outcomes and parental characteristics deserves serious consideration, because it gives the debate over the safety of ART a decidedly eugenic cast.

348. ADA Amendments Act of 2008, scc. 4, § 12102(2)(B), 122 Stat. at 3555; see also Bragdon, 524 U.S. at 639 (recognizing reproduction as a major life activity).

349. See ADA Amendments Act of 2008, sec. 4, § 12102(4)(E), 122 Stat. at 3556 (stating that mitigating measures that should not be considered when determining disability include "medication, medical supplies, cquipment, or appliances, low-vision devices (which do not include ordinary eycglasses or contact lenses), prosthetics including limbs and devices, hearing aids and cochlear implants or other implantable hearing devices, mobility devices, or oxygen therapy equipment and supplies"). Congress made this amendment to repudiate Sutton v. United Air Lines, Inc., 527 U.S. 471 (1999), and other cases holding that whether an impairment substantially limits a major activity must be determined in light of the ameliorative effects of mitigating measures. See sec. 2(b)(4), 122 Stat. at 3554 (stating that the holding in Sutton eliminated the ADA's protection for many people Congress intended to protect).

350. But see in fra text accompanying note 360 (discussing the "infertility time bomb" argument).

351. See supra Part I.A.

352. See supra Part III.

353. See supra Part I.B. 


\section{Regulation as the New Sterilization}

To address the third point, we must consider whether laws that ban or restrict ART interfere with reproduction, as eugenic sterilization laws did.

Sterilization laws compelled fertile individuals to undergo vasectomies and tubal ligations. ${ }^{354}$ By contrast, no one advocates that infertile men and women should be sterilized. Physically they will remain untouched.

However, there are two important similarities between ART regulation and sterilization laws. First, both bring the coercive power of the government to bear upon the individual. ${ }^{355}$ Second, both take away the opportunity to conceive children. The state need not wield the scalpel when it can simply ban the technologies that infertile men and women need to reproduce.

In fact, there is reason to believe that legal restrictions on ART could be more effective (and thus more oppressive) than sterilization laws ever were. Identifying and sterilizing victims took significant time and expense. Since sexual intercourse could take place in private, those subject to eugenic sterilization had a ready means to defy the laws and continue reproducing.

The infertile have fewer options. They can have all the private sex they want, but it will do them no reproductive good. Instead, they must gain access to doctor's offices, clinics, and pharmacies. But, these are chokepoints where regulators can block illicit reproduction before it occurs.

To be sure, infertile men and women might travel to other countries for access to ART, but that significantly increases the cost of an already expensive treatment. Moreover, there is no guarantee that they will gain access to the treatments they need in foreign countries. Rather, it has been foreigners who come to the United States in an effort to escape the restrictive laws and regulations that already exist in their own countries. ${ }^{356}$ A crackdown on ART in the United States could not only leave Americans without options, but have eugenic effects around the world.

\section{Eugenic Goals}

The last point to consider is whether laws that ban or restrict ART and eugenic sterilization laws have common goals. This section examines three goals: improving the species, saving money, and protecting the unborn from their own flawed existence.

\section{a. Improving the Species}

Eugenicists wanted to improve the human species. ${ }^{357}$ They believed

354. See generally Buck v. Bell, 274 U.S. 200(1927) (requiring the cutting of the fallopian tubes of a young woman who was believed to be an imbecile and who had already borne a child).

355. See supra Part II.

356. See Alcx Bamum, For Infertile Couples, It's California or Bust-State Has Become Major Destination for Making Babies, S.F. CHRON., Aug. 15, 2005, at Al, available at http://articles.sfgate.com/ 2005-08-15/ncws/17384764_1_pacific-fertility-center-clinics-cgg-donation (cstimating that a few thousand people, including gays and lesbians, from countrics that restrict ART visit Califomia for fertility treatment cach year).

357. See Albert Edward Wiggam, The New Decalogue of Science 105 (1922) [hereinafter 
crime, insanity, disability and sickness could be solved within just a few generations through selective breeding. ${ }^{358}$ Towards that end, they tried to stop the "unfit" from reproducing and passing their allegedly inferior genes to the next generation. ${ }^{359}$

This author has discovered two species-oriented arguments against ART in the course of her research. First, some believe that IVF and ICSI have unleashed an "infertility time bomb" upon the unsuspecting fertile population. The Darwinian account goes something like this: Nature would ordinarily weed infertile men and women and their inferior sperm and eggs out of the gene pool, but technology is preventing that from happening. Instead, the infertile are breeding more infertile to the detriment of the human species, which may itself be rendered infertile. ${ }^{360}$

The time bomb argument rests on shaky assumptions. Infertility is not always heritable. It has many non-genetic causes, including scarring from venereal disease and delayed childbearing. ${ }^{361}$ Thus, it is scientifically inaccurate to assume that every man or woman who employs ART is transmitting infertility to the next generation. Moreover, even though some men and women do harbor genetic defects in their sperm and eggs, it is highly unlikely that IVF and/or ICSI will cause the infertile to outnumber the fertile and doom the species.

A recent article addressed the concern that ICSI could transmit $Y$ chromosome deletions to the sons of infertile men, thereby precipitating a future decline in male fertility. ${ }^{362}$ Assuming that $1 \%$ of infertile men had a transmissible genetic defect, even if half of such men used ICSI to sire children, the authors concluded it would take two hundred years to double the already low rate of such infertility. ${ }^{363}$ Total male infertility was very unlikely due to the prospect of biomedical progress and social and economic factors that limited the number of men able to benefit from ICSI. ${ }^{364}$

Second, the FDA's decision to halt ooplasm transfer also reflected

Wiggam, New DeCalogue of SCIEnCE] ("Eugenics is, I repcat, not a mere program-it is a change in the perspective of civilization, character and life. It is a new kind of humanism"); Sonia M. Sutcr, A Brave New World of Designer Babies? 22 BERKELEY TECH. L.J. 897, 904 (2007) (providing history on cugenics).

358. See PAUL, supra note 310 , at 68 (quoting some cugenicists' belicf that cugenics could climinate "practically all of the cacogenic varietics of the race").

359. Those considered to have inferior genes included the fecbleminded, the insane, epileptics, epileptics, alcoholics, drug addicts, those afflicted with discase or suffering from blindness or deafness, criminals, orphans, the homcless, and paupcrs. Paul A. Lombardo, Medicine, Eugenics, and the Supreme Court: From Coercive Sterilization to Reproductive Freedom, 13 J. CONTEMP. HEALTH L. \& POL'Y 1, 3 (1996).

360. See, e.g., Jens Peter Ellckilde Bonde \& Jøm Olsen, Interpreting Trends in Fecundity Over Time Is Complicated by the Lack of Direct Markers, 336 BMJ 339, 339 (2008) ("With the advent of assisted conception, subfertile couples may have as many children as fertile couples, so that genetic factors linked to infertility will become more prevalent in the generations to come."); Smith, supra note 8 (stating that infertile couples are using IVF to have children). See also Eric A. Posner \& Richard A. Posner, 7 he Demand for Human Cloning, 27 HofSTRA L. REv. 579, 596-99 (1999) (speculating that if infertile people are allowed to reproduce through cloning, infertility will "spread like a virus" and infertilc clones will come to dominate the population)

361. See Smith, supra notc 8 (stating that there arc multiple causes to infertility).

362. See generally Malcom J. Faddy ct al., Intra-cytoplasmic Sperm Injection and Infertility, 29 NATURE GENETICS 131 (2001) (discussing that ICSI may lead to increased infertility).

363. Id.

364. See id. (stating that even though IVF could increase the occurrence of infertility by passing on the infertility causing genes, external factors that limit access to IVF will prevent "total malc infertility"). 
concern for the genetic condition of the human species. The agency not only asserted that a mixture of mitochondria could cause disease, but also complained that ooplasm transfer effected a genetic modification that the resulting child could pass on to future generations. ${ }^{365}$ Thus, by blocking the technique, the agency acted to prevent "bad" mitochondrial genes from spreading and having inter-generational effects.

\section{b. Saving Money}

Eugenicists wanted to save money. ${ }^{366}$ They recognized that some disabled men and women could not support a family, but believed these individuals could at least support themselves. ${ }^{367}$ Therefore, they viewed sterilization as key. ${ }^{368}$ The procedure could facilitate the release of inmates from expensive public institutions ${ }^{369}$ and reduce the number of children with heritable defects who otherwise would burden taxpayers and social services. ${ }^{370}$ As the Great Depression took hold, such financial rationales for sterilization became more dominant. ${ }^{371}$

Eighty years later, financial concerns are now being asserted as grounds to control ART. For example, consider the furor over Nadya Suleman, a single woman who already had six children but used IVF to give birth to eight more in 2009. In a panicky era when layoffs were widespread and stock markets down, the public and lawmakers expressed rage at the thought that this mother and her brood could end up on welfare at taxpayer expense. ${ }^{372}$ Legislators introduced bills to limit the number of embryos transferred during IVF, not only to protect child health, but to save the public purse. ${ }^{373}$

Though the "Octomom"374 controversy may seem limited to the specific issue of multiple-embryo transfer, it is not hard to find similar reasoning in the general debate over the health impacts of ART. Recall that the President's

365. See supra text accompanying notes 124-27 (recognizing that genetic modification of embryos alters the genetic makcup of children conceived through IVF. In one example, a child had two sets of mitochondrial DNA).

366. See REILLY, supra note 315 at 94 (stating that one goal of cugenics "was to reduce new burdens on the public purse").

367. See id. (explaining how cugenics was "concemed with preventing parenthood in those individuals who were thought to be unable to carc for children").

368. Id. at 92 .

369. See id. at 91-92 (discussing how cugenicists belicved sterilization would allow "defective persons" to leave state-funded institutes).

370. See PERnICK, supra note 316, at 91-92 (discussing how cugenics is for the "collective good" of socicty).

371. See KeVLES, supra note 307, at 113-15 (noting the increasing numbers of mentally disabled people and the public cost of caring for them and discussing how cugenicists attributcd uncmployment and low sociocconomic status to mental incapacity).

372. See Shaya Taycfe Mohajer, Taxpayers May Bear Cost of Raising Octuplets, S.F. CHRON., Fcb. 12, 2009, at A6 (discussing the amount of public funding required to carc for Sulcman's octuplets).

373. Yoshino \& Garrison, supra notc 77 (discussing various bills to limit multiplc-cmbryo transf er); see Airan Scruby, Octuplet Birth Might Spawn New Laws, SAN GaBriel VAlley TriB., (Fcb. 13, 2009), available at http://www.sgvtribunc.com/news/ci_11703244 (describing California Statc Senator Sam Aancstad's planned bill to prohibit the state from paying medical bills for multiples born using IVF and to regulate IVF to prevent multiple births).

374. See, e.g., Airan Scruby, Charity Says It Needs Donations for Octomom, San Gabriel Valley TRIB., (Mar. II, 2009), available at http://www.sgvtribunc.com/ci_11890699 (mentioning the term "Octomom," which is a sensationalistic term the media and public have adopted to describe Nadya Sulcman). 
Council on Bioethics released a report in 2004 emphasizing the increased risks to children conceived through ART. ${ }^{375}$ In that report, the Council opined that patients and doctors were not the only ones who must decide whether increased risk was justified; society as a whole had to address that question, particularly if it would bear the costs of caring for offspring with health problems. $^{376}$

The Council's point was only too clear: He who pays the piper must call the reproductive tune, all in the name of the public good. It bears emphasizing that this disturbing message did not come from some muckraking journalistic account about "Octomom"; rather, it came from a prestigious national body of experts appointed to consider biotechnological issues and provide the nation with ethical guidance.

American policymakers are not alone in articulating such sentiments. As two European scientists commented upon surveying the health impacts of ART, the desires of would-be parents must be balanced against those of deformed children "and the society that might have to provide increased support for them.",377

\section{c. Protecting the "Better Not Born"}

Last but not least, eugenicists wanted to relieve human suffering. In their view, parenthood weighed heavily upon the "unfit" and life itself was a burden to offspring with heritable defects. ${ }^{378}$ Thus, Karl Pearson, a prominent British eugenicist, described eugenics succinctly as the "better not born" doctrine. 379

Albert Wiggam, an American eugenicist, emphasized this point in his popular books:

You fondly imagine you can speed up evolution with cakes and cream for the unfit. But nature has progressed by letting the devil take the hindmost. Your method is to increase the number of the hindmost. Nature slaughters the innocents, but you merely throw more innocents into her ravenous maw. Your very mercy often only adds to nature's brutality. ${ }^{380}$

Wiggam offered the nation a new Golden Rule as enhanced by biological

375. See supra tcxt accompanying notcs $153-60$.

376. See REPRODUCTION AND RESPONSIBILITY, supra notc 61 , at 42 (stating that becausc babics conccived through ART have an incrcased risk of health problems, socicty must decide if the risk is justificd becausc taxpaycrs might bcar the cost of caring for the babics).

377. See Sutcliffe \& Ludwig, supra notc 283, at 357 (cxplaining that socicty necds to balance the necds of the children-specifically those conceived through IVF-against parents' desire for children conceived through IVF).

378. See Victoria F. Nourse, In Reckless Hands: Skinner v. OKLahoma and the Near Triumph OF AMERICAN EUGENICS 21 (2008) (cxplaining that many vicwed cugenics as a means of alleviating the suffering of both parents whose offspring had heritable defects and the offspring themselves); Suter, supra note 357, at 947 (noting how cugenicists argued that a parent who gave birth to a fecbleminded child would fecl despair for the child, thercby intimating that stcrilization benefited both parents and the unborn).

379. PERNICK, supra notc 316, at $195 \mathrm{n} .41$; see also KEVLES, supra note 307, at 90 ("The supcrficially sympathetic man flings a coin to the beggar; the more decply sympathetic man builds an almshousc for him so that he necd no longer beg; but perhaps the most radically sympathetic of all is the man who arranges that the beggar shall not be born." (quoting HAVELOCK ElLIS, THE TASK OF SOCIAL HYGIENE 401 (1912)) (cmphasis addcd).

380. WigGam, supra notc 357 , at 55 . 
understanding, one that he claimed Jesus Christ himself would have approved: "Do unto both the born and the unborn as you would have both the born and unborn do unto you. ${ }^{381}$ This is the real golden rule. This is the biologist's conception of the brotherhood of man.",382

The Buck v. Bell decision expressed the same attitude. Writing for the Court, Justice Oliver Wendell Holmes reasoned: "It is better for all the world, if instead of waiting to execute degenerate offspring for crime, or to let them starve for their imbecility, society can prevent those who are manifestly unfit from continuing their kind." 383 In other words, rather than relegate "degenerate offspring" to terrible deaths through execution or starvation, Holmes deemed it better for the entire world-including the offspring themselves - if they simply never came into existence. This view resonated with the views of Pearson, Wiggam, and others who believed eugenics showed sincere compassion towards the unborn.

Returning to the field of assisted reproduction, we find that legislators and regulators have already banned cloning, nuclear transfer, and ooplasm transfer on the reasoning that resulting children are at risk of health problems. These laws and regulations exemplify the belief that such children are better off never born.

If the government next attempts to ban or restrict IVF, ICSI, or related technologies on safety grounds, it will be employing the same "cruel-to-bekind" reasoning. Some infertile men and women can reproduce only through these technologies. Laws that block access might succeed in reducing birth defects, rare disorders, and poor perinatal outcomes, but only by eliminating the children along with them. Such laws reflect a value judgment that nonexistence is preferable to life with certain physical defects or conditions. ${ }^{384}$ The harshness of this judgment becomes all the more apparent when one remembers that even major birth defects can often be corrected through surgery ${ }^{385}$ and that most preterm infants go on to lead healthy and normal lives. 386

\section{Is the New Eugenics a Bad Thing?}

The foregoing parallels lead to the conclusion that the historical analogy is valid. Laws and regulations restricting access to ART on the ground that the resulting children might suffer from health problems are eugenic in character, and bear more than a passing resemblance to the sterilization laws of the twentieth century.

381. Id. at $110-11$.

382. Id.; see also AMERICAN Eugenics Societr, A Eugenics CATECHISM 2 (1926) (arguing that true kindness requires taking steps to reduce births of "hereditary defectives").

383. Buck v. Bcll, 274 U.S. 200, 207 (1927).

384. See Ken R. Danicls ct al., The Best Interests of the Child in Assisted Human Reproduction: The Interplay Between the State, Professionals, and Parents, 19 POL. \& LIFE SCI. 33, 37 (2000) ("[I]f the best interests of hypothetical children are optimized by their not being conceived, has the argument moved from a high-minded concern for of fspring welfare to an unacceptable form of eugenics?").

385. See supra notes 177-78 (discussing major birth def ects that can be corrected through surgery).

386. Ecro Kajantic ct al., Young Adults with Very Low Birth Weight: Leaving the Parental Home and Sexual Relationships Helsinki Study of Very Low Birth Weight Adults, 122 PEDIATRICS c62, c62 (2008). 
The question remains: Is this brave new eugenics a bad thing? Or can we embrace it without fear or regret? In searching for an answer, this Article reasons by analogy to critiques of twentieth-century eugenics.

\section{Coercive Reproductive Policies}

Professor Lombardo has opined that "governmental involvement in coercive reproductive policies is the most objectionable feature of eugenics to most people today." ${ }^{\text {,87 }}$ In other words, we remember sterilization laws unfavorably because they took away the ability of adults to decide for themselves whether to have children. The state substituted its own judgment, which was that certain people should not have children. Victims experienced not only a loss of autonomy, but also a loss of children and posterity.

Many infertile men and women cannot have children without the aid of IVF, ICSI, and the like. Therefore, laws or regulations restricting access to these technologies would take away their ability to decide for themselves whether to have children. The state would substitute its own judgment, namely, that those who need ART should not have children. Again, victims would experience not only a loss of autonomy, but also a loss of children and posterity. Such coercive laws and regulations would be out of step with the present culture, which cherishes reproductive autonomy. ${ }^{388}$

\section{Tyranny of the Majority}

This train of thought leads naturally to the next topic of concern. Twentieth-century eugenics has been criticized for its oppression of the disempowered. ${ }^{389}$ Eugenicists used education and moral suasion to encourage middle and upper-class Americans to reproduce and spread their genes. ${ }^{30}$

387. Lombardo, supra note 141 , at 216 .

388. See PaUL, supra note 310, at 71 ("Revelations of Nazi atrocities, the trend toward respect for patients' rights in medicine, and the rise of feminism have converged to make reproductive autonomy a dominant value in our culture."). Whether such laws and regulations would infringe procreative liberty in the constitutional sense is a complicated question beyond the scope of this Article. The Supreme Court has stated in dicta that substantive duc process protects the right to procreatc. See, e.g., Lawrence v. Texas, 539 U.S. 558, 574 (2003); Planned Parenthood v. Cascy, 505 U.S. 833, 851 (1992); Carcy v. Population Services Int'l, 431 U.S. 678, 685 (1977) (all indicating protection of the right to procrcate in certain circumstances). Since procreation is seldom outlawed or restricted, the Court has not had the opportunity to address directly the right to procreate through coitus or ART. However, a federal district court has recognized the constitutional right of an infertile woman to procreatc, including through technologics such as cmbryo transfer. See Lif chez v. Hartigan, 735 F. Supp. 1361, 1376-77 (N.D. III. 1990) (“'WW]ithin the cluster of constitutionally protected choices that includes the right to have access to contraceptives, there must be included within that cluster the right to submit to a medical procedure that may bring about, rather than prevent, pregnancy."), aff $d, 914 \mathrm{~F} .2 \mathrm{~d}$ 260 (7th Cir. 1990) (unpublished opinion). Academic opinion is divided on the question of whether there is a constitutional right to procreate through ART. Compare Robertson, supra note 297, at 25 (arguing the right to procreatc includes ART) with Ann Macl_can Massic, Regulating Choice: A Constitutional Law Response to Professor John A. Robertson's Children of Choice, 52 W ASH. \& LEE L. REV. 135, 135 (1995) (contending the right to procreate protects only coitus).

389. See Suter, supra note 357, at 958 (arguing neocugenics makes it more likely for people to identify individuals in terms of their disabilitics or undesirable traits, which is harmful to vulnerable members of the community).

390. The American Eugenics Society and like-minded organizations funded lectures, meetings, journals, cducational films, and exhibits. There even were contests at state fairs where families competed like livestock based on medical history, intelligence testing, physical examination, and psychiatric assessment. KEVLES, 
Meanwhile, sterilization laws curbed the reproduction of groups whom the majority considered "unfit," such as criminals and the disabled. ${ }^{391}$ Though poverty was not grounds for sterilization, poor men and women were at greater risk. ${ }^{392}$ Lack of proper nutrition and health care increased the odds of disease, and poverty brought them into contact with courts and public institutions that had the power to classify them as mentally deficient. ${ }^{393}$

This history reminds us that democracy has an ugly side. Those who already have privilege can vote themselves more. The sterilization laws of the twentieth century were used to oppress individuals who had the bad luck to be poor, physically or mentally disabled, or convicted of a crime. ${ }^{394}$

Returning to ART, infertile men and women who use IVF and ICSI tend to be white and have enough money to pay for treatments even when health insurance does not cover them. ${ }^{395}$ At first glance, they would not seem to be a group vulnerable to oppression.

However, this narrow view ignores three points. First, infertile men and women are a minority of the population. ${ }^{396}$ Most in this minority are treated with drugs or surgery; less than $5 \%$ of infertility services involve IVF and the like. ${ }^{397}$ Thus, ART patients are a minority of a minority. Fertile men and women far outnumber them and have the political muscle to strip them of children through the ballot box.

Second, infertility carries a social stigma, and many infertile men and women are severely depressed. ${ }^{398}$ Few are likely to have the energy or courage to come out of the closet and bare their souls in an effort to persuade the fecund majority not to restrict ART. Fertility doctors may advocate for them, but their financial interest makes them less likely to garner public sympathy and support.

Third, Congress enacted the ADA to protect the disabled against discrimination, including at the hands of public entities. As explained above, many infertile men and women are properly classified as disabled under the ADA. ${ }^{399}$ Thus, the ADA reflects a congressional judgment that the infertile are indeed disempowered.

Here again, the lesson of history is clear. If lawmakers and regulators take ART away from infertile men and women, their actions could be viewed (and later condemned) as oppression of the members of a vulnerable minority

395. See Judith F. Daar, Accessing Reproductive Technologies: Invisible Barriers, Indelible Harms, 23 BERKELEY J. GENDER, L. \& JUST. 18, 39-40 (2008) (discussing how low-income, nonwhitc individuals have higher rates of infertility, but still have less access to fertility treatment).

396. Infertility, EPIGEE, http://www.epigee.org/health/infertility.html (last visitcd Sept. 18, 2010).

397. See Frequently Asked Questions Abøut Infertility, ASRM, http://www.reproductivefacts.org/awards/ index.aspx?id=3012 (last visited Sept. 18, 2010) (answering frequently asked questions about infertility and its treatments).

398. See Daar, supra note 395, at 29-30 (discussing the emotional and psychological cffects of infertility).

399. See supra tcxt accompanying notcs 345-349.
} 
group.

\section{Stigma and Inequality}

Thus far, the discussion has centered on the impact that regulation could have on infertile men and women who need IVF, ICSI, and related technologies to reproduce. Though these are the most obvious victims of the brave new eugenics, they are not the only ones.

Twentieth-century eugenicists argued that children with bad genes should never be conceived because they would suffer too much. ${ }^{400}$ Though sugarcoated with compassion, this argument was based on the assumption that some lives were more worth living than others. At its core, the compassionate case for eugenics was as virulently anti-egalitarian as the rest of the movement.

Despite the best of intentions, the drive to control ART on the ground that it is unsafe for children falls into exactly the same trap. Blinded by inapt analogies to laws that protect the interests of existing fetuses or children, ${ }^{401}$ its proponents fail to see the eugenic implications of regulating ART to prevent the very conception of children.

Infertile men and women suffer from a variety of medical conditions. Some of these conditions hold the potential to impair the health of offspring. Any move to take ART away from the infertile---or a subset of them, such as severely infertile men who need ICSI-necessarily implies that they are too flawed to reproduce, and that their children are too unhealthy to exist. When the case for ART regulation is viewed through the lens of current medical research, its ultimate logic comes uncomfortably close to a Darwinian judgment that only the fittest should exist.

That judgment has two consequences. First, it is stigmatizing. Infertility is a disability that already deals a hard blow to the dreams and self-esteem of millions of men and women. If, on top of that, the law blocks their only means of reproducing on the ground that their children run too high a risk of health problems, it sends a dehumanizing message: the infertile are not worthy of reproducing and contributing to the species. ${ }^{402}$

But, the message does not stop there. Children conceived through ART also are stigmatized as being too flawed to exist, along with anyone else who happens to have birth defects, rare disorders, or perinatal outcomes of the same kind used to justify laws restricting access to ART. Because millions of such

400. See, c.g., Lombardo, supra note 141, at 204 (citing Charles B. Davenport's opinion which suggests the suffering of individuals with bad genes).

40I. Consider, for example, a recent article by Professor Marsha Garrison. Garrison, supra note 90. Arguing for increased regulation of ART, she draws analogics to: adoption, which is regulated to safeguard adopted children, id. at 1626-27; state neglect laws that protect fetuses and children against parental health carc choices that are harmful; wrongful death and criminal statutes that protect fetuses; human subject rescarch regulations that limit experimentation on children; and federal law that prohibits federally-funded hospitals from withholding care from disabled newboms. Id. at 1641. But all of these other laws address existing fetuses or babies whose characteristics have already been determined, not by the state, but by the reproductive choices of parents.

402. Cf. Daar, supra note 395 , at 76 (arguing that laws and clinic screening practices that deny ART based on wealth, ethnicity, racc, marital status, or sexual orientation express the view that the rejected patient is unworthy of parenthood and membership in the human race). 
persons already exist, the message can damage their self-esteem and place them at risk of employment and insurance discrimination. ${ }^{403}$

Second, laws that stigmatize in this way undermine our commitment to egalitarianism. In a society that claims to view all men and women as equals, the government should not only talk the talk, but walk the walk. It should not arrogate to itself the power to decide which lives are worth living and which are not. Such judgments run contrary to the very principle of equality, and entice us down a slippery slope in which further damaging judgments can be made on the strength of bad precedent. ${ }^{404}$

\section{Science and Politics}

Twentieth-century eugenics is easy to criticize on scientific grounds. For example, eugenicists thought they could eradicate undesired traits through sterilization. But, some traits are linked to recessive genes. It does no good to control the reproduction of the unlucky few who manifest the genes if those who appear normal continue to pass the recessive genes along to their offspring. ${ }^{405}$ And eugenicists made other big mistakes too, such as failing to recognize that undesired traits may result when genes interact with the environment. ${ }^{406}$ Physical and mental deficiencies can result from something as simple as inadequate nutrition. ${ }^{407}$ The people who Wiggam derided for wanting to provide "cakes and cream for the unfit" turned out to be correct. ${ }^{408}$

Today our understanding of genetics and epigenetics is more sophisticated. We also have access to a lot of research on children conceived through ART.

This raises an interesting question: are laws with eugenic implications acceptable when based on accurate science? Lawmakers and regulators might take that position, reasoning that restrictions on ART are worthwhile so long as they really do protect children.

Even that stance is problematic, however. To explain why, this Article will evaluate two kinds of laws and regulations: those that control ART in general, and those that control the reproduction of infertile men or women with particular characteristics.

\section{a. Technology Controls}

As discussed above, some researchers have found that children of ART have an increased risk of birth defects, rare disorders, and poor perinatal outcomes. $^{409}$ Suppose lawmakers and regulators read the research and decide

\footnotetext{
403. Cf. MACINTOSH, supra note 43, at 120-23 (discussing the stigma that anti-cloning laws inflict upon human clones).

404. Cf. id. at 130-33 (arguing that anti-cloning laws undernine commitment to egalitarianism).

405. See William R. Matoush, Eugenic Sterilization-A Scientific Analysis, 46 DENV. L.J. 631, 643 (1969) (stating that carriers of defects frequently do not physically manifest those defects for generations).

406. See id. at 639-42 (cxplaining that gencs may predispose to schizophrenia and other mental illnesses but environmental factors also play a role in the expression of these discases).

407. KEVLES, supra note 307 , at 143

408. See supra text accompanying note 380 .

409. See supra Part III.
} 
to ban or restrict ART to protect the saf ety of children. Is that a decision based on good science?

As this Article has explained, there is good reason to believe that these health problems (which occur only in a minority of children) can be traced back to the underlying chromosomal, genetic, and epigenetic characteristics of a subset of infertile men and women. ${ }^{40}$ Those who believe ART is unsafe have overlooked this point.

This illustrates a problem with using science as a rationale for restricting autonomy. What appear to be obvious answers sometimes turn out to be misinterpretations of data. Moreover, science is always advancing. Research that appears to be correct this year may turn out to be incorrect the next. ${ }^{411}$ An y lawmaker or regulator who restricts ART runs the risk that she will end up like twentieth-century eugenicists, condemned for well-meaning reliance on science that later turned out to be wrong.

In theory, lawmakers and regulators could adjust laws and regulations to take new scientific information into account. But, history teaches that it can be hard to stop a bad idea once it gathers momentum.

Critics raised questions about twentieth-century eugenics early on. By 1917, geneticists were already discussing the fact that recessive genes could not be purged from a large population. ${ }^{412}$ This insight should have ended the eugenics movement. Instead, the movement gathered momentum. Many eugenicists continued to rely on biological rationales, contending that any effort to stamp out bad genes was better than none. ${ }^{413}$ Others shifted tactics and argued the "unfit" should be sterilized because it cost money to institutionalize them ${ }^{414}$ and they were incapable of parenting a child. ${ }^{415}$ This example shows that public policies can be hard to change, particularly when an issue as complicated and sensitive as human reproduction is involved.

\section{b. Patient Controls}

What about the fact that some infertile men and women do indeed have a higher risk of transmitting chromosomal, genetic, or epigenetic problems? Does that justify laws or rules blocking such individuals from accessing ART? ${ }^{416}$

Lawmakers and regulators could probably establish a few workable rules. For example, they could order doctors to refuse treatment to individuals who

\footnotetext{
410. Id.

411. See Suter, supra note 357, at 946 (arguing against the privileging of contemporary standards of science)

412. See PAUL, supra note 310 , at 68 (discussing the findings of Harvard geneticist, Edward East).

413. See id. at 69 ("... the fact that we cannot do everything is not a valid reason for neglecting to do what littlc can be donc...").

414. See REILLY, supra note 315, at 101-102 (citing studics that proved sterilization had proven its value since sterilized persons cost the state less moncy than had the nonsterilized parole groups).

415. See id. at 89 (noting physicians' concerns were shifting from the control of genetic disorders to reducing procreation by socially inadequate parents)

416. Cf. Raymond D. Lambert, Safety Issues in Assisted Reproductive Technology: Aetiology of Health Problems in Singleton ART Babies, 18 HUM. REPROD. 1987, 1990 (2003) (noting that further study is needed to determine which infertile women are at risk of poor outcomes, so that doctors can offer treatment only to low-risk patients).
} 
are found to carry chromosomal abnormalities such as balanced translocations. They could establish an age limit for women, since age increases the risk of conceiving disabled offspring. They might even ban ICSI for men with Y chromosome deletions.

Beyond that, however, it would be extremely difficult to fashion workable controls. Researchers believe that minor chromosomal deletions, genetic mutations, and epigenetic factors contribute both to infertility and offspring health problems, but scientific knowledge remains incomplete. It would be very hard to identify affected men and women and block their access to ART.

Moreover, legislation and regulation that targeted older women and others at risk for transmitting chromosomal, genetic, or epigenetic abnormalities would heighten the equality-based concerns discussed above. Overpowered by the fertile majority (and perhaps abandoned by other infertile men and women desperate to retain their own access to ART), this small subgroup would have a difficult time obtaining relief through the democratic process. Random biological or medical factors would exacerbate the unfairness: some with disfavored characteristics would eventually succeed in reproducing through sex or simpler medical interventions (such as fertility drugs), while others would remain forever childless.

There is one bright side to legislation or regulation based on patient characteristics. Once matters such as age and genes are frankly discussed, the eugenics of any such proposal will become more obvious. Even the most oblivious legislator or regulator might recognize the historical parallels and recoil. $^{417}$

To summarize this Part, it is reasonable to anticipate that legislators or regulators could assert health problems in children as grounds to ban or restrict access to IVF and ICSI. This Part has argued that such restrictions would be the practical equivalent of mandatory sterilization laws, imposed against a class of disabled persons (the infertile) to prevent them from transmitting health problems to offspring. This brave new eugenics threatens to perpetrate the same wrongs as before: coercive reproductive policies, oppression of a minority group, and stigma, all in the name of imperfect science.

\section{CONCLUSION}

Today, we remember the eugenics movement of the twentieth century primarily in terms of its drive to improve the gene pool. We recall that eugenicists forged ahead at the expense of those who were disabled and poor. What we tend to forget is that the eugenics movement had a softer side. Sterilization was considered a compassionate response to those who were "better not born."

417. In addition, Icgislation or regulation based on patient characteristics could lead to some surprising results. For example, a proposed law to prevent older women or carriers of genetic or epigenetic anomalics from accessing ART would kecp some married heterosexuals from having children; meanwhile, young and healthy singles, gays, and lesbians would be left free to reproduce through ART. Conservative legislators who believe heterosexual marriage is the foundation of family might refuse to enact such a law. 
This aspect of twentieth-century eugenics should not be overlooked, for it links the past and present to a potential legal future that is frighteningly appealing to many well-intentioned people. Regulators have already made novel treatments such as cloning, nuclear transfer, and ooplasm transfer illegal. Conventional technologies such as IVF and ICSI now have come under fire, with federal policymakers demanding more studies of their safety and academics proposing tougher regulation, all in the name of protecting children.

The possibility that parental characteristics may be to blame for health problems observed in children of ART has been largely overlooked. Advocates of increased governmental control over ART have failed to recognize the eugenic implications of acting to "protect" children from their own existence.

That public eugenics should reemerge in the twenty-first century, speaking solemnly about the welfare of children, should give us all serious pause. Whatever the dangers of ART may be, they are nothing compared to the power of the state to relegate a class of disabled persons to childlessness based on the prejudgment that the lives of their offspring are not worth living. Such discrimination betrays our core values and must not be tolerated. 